\title{
ECOLOGIA DA POLINIZAÇÃo, FLUXO DE PÓlEN E TAXA DE CRUZAMENTO EM Bauhinia forficata Link. (Caesalpiniaceae)
}

\author{
ELZA MARIA GUIMARÃES SANTOS \\ Bacharel em Ciências Biológicas
}

Orientador: Prof. Dr. PAULO YOSHO KAGEYAMA

Dissertaçăo apresentada à Escola Superior de Agricultura "Luiz de Queiroz", da Universidade de São Paulo, para obtenção do título de Mestre em Agronomia, Área de Concentraçno : Genética e Melhoramento de Plantas.

PIRACICARA

Estado de Säo Paulo - Brasil

Outubro - 1994 
Ficha catalografica preparada pela Secăo de Livros da Diviszo de Biblioteca e Documentagá - FCLQ/USp

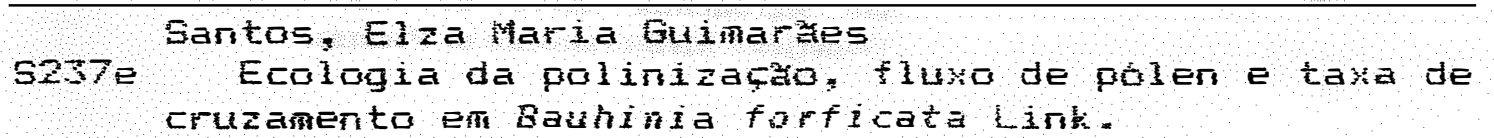
(Caesalpiniaceae). Firacicaba, 1994. 1149 .

Diss. (Hestre) - ESALQ Eibliografia.

1. Ecalogia florestal 2. Mororo - Cruzamento 3. Mororo - Folinizaça I. Escola Superior de Agricultura Luiz de Queiroz, Piracicaba 


\section{ECOLOGIA DA POLINIZAÇÃO, FLUXO DE PÓlEN E TAXA DE CRUZAMENTO EM Bauhinia forficata Link. (Caesalpiniaceae)}

\section{ELZA MARIA GUTMLARÃES SANTOS}

Aprovada em : 29.11.1994

Comissão julgadora :

Prof. Dr. Paulo Yoshio Kagevama

ESALQ/USP

Prof. Dr. Paulo Sodero Martins

ESALQ/USP

Prof. Dr. Edson Seizo Mori

FCA/UNESP

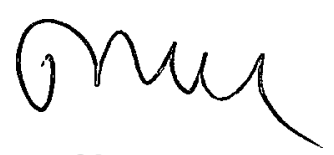

Prof. Dr. Paulo Yoshio Kageyama

Orientador 


\section{AGRADECIMENTOS}

Agradeço:

- Ao Prof. Dr. Paulo Yoshio Kageyama pela orientação e por ter me concedido a oportunidade de realizar este trabalho;

- Ao Prof. Dr. Roland Vencovsliy pelas valiosas sugestões e auxílio nas análises biométricas;

- Ao Prof. José Augusto Piratelli pelo auxilio na coleta dos exemplares de Chiroptera;

- Ao Prof. Dr. Keith Brown pela identificação dos exemplares de Lepidoptera;

- Ao especialista Wagner André Pedro pela identificação dos exemplares de Chiroptera;

- Ao Departamento de Entomologia da ESALQ/USP e João Ângelo Cerignoni, pela identificação dos exemplares de Lepidoptera e Hymenoptera;

- Ao Sr. Gonçalo Mariano pelo auxílio na localização das árvores na Estação Ecológica de Ibicatu;

- Ao colhedor de sementes Leonardo de Souza pela prestatividade durante a realização das coletas;

- Ao IPEF-ESALQ/USP por ter cedido um funcionário para coleta das sementes utilizadas neste trabalho;

- Ao Instituto Florestal da Secretaria do Meio Ambiente do Estado de São Paulo pela permissão para realização do tra- 
balho na Estação Ecológica de Ibicatu, Piracicaba (SP);

- Ao Conselho Nacional de Desenvolvimento Cientifico e Tecnológico ( $\mathrm{CNPq}$ ) e Coordenadoria de Aperfeiçoamento de Pessoal de Ensino Superior (CAPES) pela bolsa concedida;

- Aos docentes do Departamento de Genética e Melhoramento de Plantas da ESALQ/USP pela importante contribuição na minha formação profissional;

- A Léia, secretária do Curso de Pós-Graduação em Genética e Melhoramento de Plantas, por sua dedicação e prestatividade;

- A Sueli Penteado pela sua colaboração em diversas etapas, especialmente no trabalho de campo;

- A Elza Martins Ferraz, pela sua colaboração durante as análises de eletroforese e pelo apoio pessoal e amizade no decorrer deste trabalho;

- Ao Flávio pelas sugestões finais e por sua amizade;

- A todos os alunos de graduação e pós-graduação que me auxiliaram em vários momentos durante o desenvolvimento do trabalho;

- Aos amigos Gabi e Maurício que sempre estiveram ao meu lado, colaborando intensamente em todos os momentos profissionais e pessoais;

- Ao Luiz, meu marido, pelo companheirismo com que compartilhou todos esses momentos comigo e, especialmente, pelo reconhecimento e valorização do meu trabalho. 
SUMÁRIO

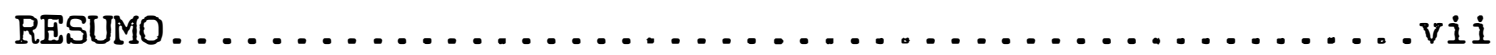

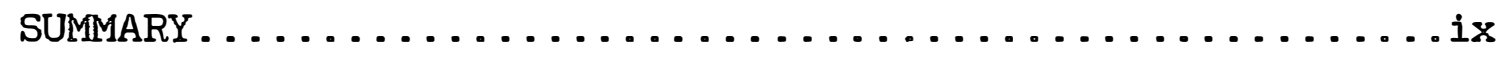

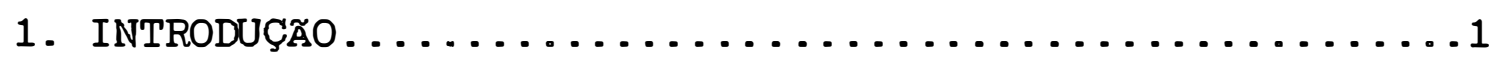

2. REVISÃO BIBLIOGRÁFICA $\ldots \ldots \ldots \ldots \ldots \ldots \ldots \ldots \ldots \ldots \ldots \ldots \ldots \ldots \ldots \ldots$

2.1. Características gerais de Bauhinia

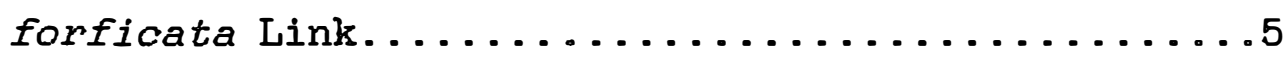

2.2. Quiropterofilia em espécies neotropicais........10 2.2.1. Quiropterofilia no gênero Bauhinia...... 14 2.3. Fluxo de pólen...................... 18 2.3.1. Considerações gerais sobre fluxo gênico...18 2.3.2. Metodologias para estimar fluxo gênico... 23 2.3.3. Dispersão de pólen em espécies zoófilas.. 26 2.3.4. Metodologias para avaliar o fluxo de pólen.

2.4. Aspectos gerais do sistema reprodutivo de espécies arbóreas................... 32

3. MATERIAL E METOdOS....................... 38

3.1. Local e população de estudo.............. 38

3.2. Avaliação da ecologia da polinização......... 39

3.3. Medidas do fluxo de pólen.............. 42

3.4. Análises eletroforéticas.............. 45

3.5. Análise dos dados isoenzimáticos.......... 50 
3.5.1. Estimativa da taxa de cruzamento aparente $(\hat{t} a) \ldots \ldots \ldots \ldots \ldots \ldots \ldots . \ldots . \ldots . \ldots 2$

3.5.2. Estimativa multiloco da taxa de cruzamento $\left(\hat{t}_{m}\right) \ldots \ldots \ldots \ldots \ldots \ldots \ldots . \ldots \ldots$

4. RESULTADOS E DISCUSSÃO................. 58

4.1. Avaliação da ecologia da polinização........ 58

4.1.1. Análise da biologia floral.......... 58

4.1.2. Análise dos visitantes florais........663

4.2. Avaliação do fluxo de pólen............. 70

4.3. Avaliação do sistema reprodutivo.......... 74

4.3.1. Estimativa da taxa de cruzamento aparente $(\hat{t} a) \ldots \ldots \ldots \ldots \ldots \ldots . \ldots . . .62$

4.3.2. Estimativa multiloco da taxa de cruzamento $(\hat{t} m) \ldots \ldots \ldots \ldots \ldots \ldots . \ldots 8$

4.4. Implicações das características da biologia reprodutiva de Bauhinia forficata.......... 91

5. CONCLUSסES. . . . . . . . . . . . . . . . . . 95

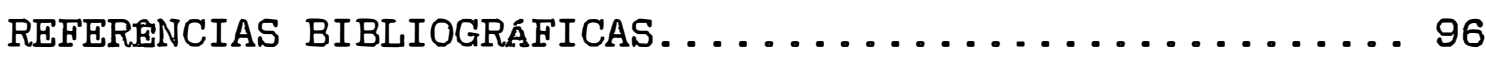
APENDICE. . . . . . . . . . . . . . . . . . . . 109 
ECOLOGIA DA POLINIZAÇÃO, FLUXO DE POLEN E TAXA DE CRUZAMENTO EM Bauhinia forficata Link. (Caesalpinaceae)

Autora: Elza Maria Guimarães Santos Orientador: Prof. Dr. Paulo Yoshio Kageyama

RESUMO

A ecologia da polinização, dispersão de pólen e sistema de cruzamento de Bauhinia forficata Link. (Caesalpiniaceae) foram estudados em uma área de vegetação secundária, localizada na Estação Ecológica de Ibicatu. As flores de Bauhinia forficata são hermafroditas e mostram características da sindrome de quiropterofilia, tais como: flores, brancas, antese noturna, flores expostas acima da folhagem e grande produção de néctar e pólen.

Esta espécie é polinizada por Carollia perspicillata uma espécie de quiróptero que visita as flores numa estratégia do tipo linha-de-captura. A transferência de pólen foi avaliada utilizando-se pó fluorescente como marcador, e a distância de dispersão de pólen observada, foi além de 200 metros da planta marcada. o modelo multiloco de cruzamento misto foi utilizado para analisar o sistema de cruzamento. A média 
das estimativas da taxa de cruzamento para os locos individuais $(\hat{t} \tilde{s})$ foi de 0,916 e a estimativa multiloco da taxa de cruzamento $(\hat{t m})$ foi de 0,982 indicando que esta espécie é predominantemente alógama.

Por outro lado as estimativas obtidas a partir da análise de variância mostram um coeficiente de endogamia $(\hat{f})$ de 0,1098 e uma taxa de cruzamento aparente $(\hat{t} a)$ de 0.8021 , revelando que a fecundação cruzada é predominante, mas baixos níveis de endogamia podem estar ocorrendo. A comparação entre as diferentes estimativas de taxa de cruzamento sugere a existência de cruzamento entre indivíduos aparentados.

o comportamento do polinizador, o fluxo de pólen à longa distância e a alta taxa de cruzamento parecem ser características importantes nos processos de colonização desta espécie, podendo levar a um aumento da variabilidade genética nas populações recém estabelecidas. 
POLLINATION ECOLOGY, POLLEN FLOW AND OUTCROSSING RATE IN Bauhinia forficata Link. (Caesalpiniaceae)

Author : Elza Maria Guimarães Santos Adviser : Prof. Dr. Paulo Yoshio Kageyama

SUMMARY

The pollination ecology, pollen dispersal and mating system of Bauhinia forficata Link. (Caesalpiniaceae) were studied in a secondary vegetation at "Estação Ecológica de Ibicatú". The flowers of Bauhinia forficata are hermaphrodict and show chiropterophilous syndrome traits such as whitish colour, nocturnal anthesis, flowers placed outside the foliage and a great production of pollen and nectar.

This species is pollinated by Carollia perspicillata, a bat which forages in a "trap-line" mode. The pollen carryover was evaluated using powdered fluorescent dyes as marker, and the mean distance of pollen dispersal from an individual plant was greater than 200 meters.

A multilocus mixed mating model was used to analyse the mating system. The mean single locus estimate 
of outcrossing $(\hat{t} \bar{s})$ was 0,916 and the multilocus outcrossing estimate $(\hat{t} m)$ was 0,982 , indicating that this species is mainly outcrossed.

However, an inbreeding coeficient $(\hat{f})$ of 0,1098 and an average outcrossing rate $(\hat{t} a)$ of 0,8021 , estimated by analysis of variance, indicate that outcrossing is prevalent, but low levels of inbreeding may be occurring. The comparison of estimates of outcrossing rates suggests existence of related mating.

The behaviour of pollinator, long distance pollen flow, and high outcrossing rate appear to be important traits for this species in the colonization process, might lead to increase genetic variability of the new populations. 


\section{1 - INTRODUSAD}

Bauhinia forficata Link. é uma espécie arborea que apresenta-se distribuida nos mais variados tipos de vegetaçao, ocorrendo na floresta Tropical Atlântica (KLEIN, 1979), nas florestas mesofilas (CORREA, 1984) @ na vegetaçao semi-árida do Nordeste (SCHACHT, 1992), e em diversos tipos de habitats tais como margens de rios, capoeiras, borda de fragmentos florestais, pastos e beiras de estradas.

As plantas de Bauhinia forficata apresentam desenvolvimento rápido, atingindo cerca de 1 metro aos 14 meses de idade, quando já apresentam florescimento e frutificaçao. Com quatro anos atingem cerca de três a quatro metros de altura, tendo a copa bem formada, abundante floresçimento e produçao de grande quantidade de frutos, apresentando inclusive. um grande potencial ormamental (BELTRATI \& PAOLI, 1989). Devido ao seu rápido crescimento e reproduça, os autores mencionados ressaltam 
que Bauhinia forficata é uma espécie de grande potencial para utilizaçăo em programas de reconstituiçăo de matas.

Os programas de reconstitutiçă e implantaçăo de florestas vêm assumindo atualmente, uma posiçao de destaque (KAGEYAMA et alii, 1989; KAGEYAMA \& CASTRO, 1988), especialmente no interior do Estado de Sao Paulo, que apresenta suas florestas quase que totalmente fragmentadas em pequenos remanescentes de floresta mesófila (MORELLATO, 1992; COSTA, 1992).

KAGEYAMA et alii, (1989) ressaltam que, para a recomposiçå da vegetaçao original, é necessário se considerar nao apenas a composiça floristica e fitossociológica da floresta, mas também a estrutura genética das populações de espécies envolvidas, visando a manutençă da biodiversidade e da variabilidade genética.

$$
\text { Atualmente vários estudos têm : sido }
$$

conduzidos no sentido de se obter informaçães sobre a biologia reprodutiva e estrutura genética de espécies tropicais. Entretanto, o conhecimento sobre o sistema reprodutivo das espécies vegetais e as complexas interaçães planta-animal nos ecossistemas tropicais tiveram impulso somente há duas décadas (JANZEN, 1971; BAWA, 1974; FRANKIE \& BAKER, 1974).

Neste contexto, HAMRICK (1987) demonstra que - sistema reprodutivo e os mecanismos de polinizaçă têm 
forte influência sobre a distribuiçă da variaça genética em plantas, sendo que as espécies autógamas apresentam baixa variabilidade dentro das populações e alta variabilidade entre as populações, enquanto que as espécies alogamas, especialmente as anemófilas, apresentam padrao oposto, ficando as espécies de fecundaçă cruzada e polinizadas por animais em niveis intermediarios entre estes dois extremos.

Outro aspecto ressaltado por MARTINS (1984) refere-se ao fato das espécies colonizadoras oferecerem excelente material de estudo na área de biologia de populações, sendo que, entre as inúmeras familias de plantas tropicais, Leguminosae oferece material adequado para estudos experimentais nesta área, especialmente em relaça as estratégias adaptativas utilizadas na colonizaçao de habitats abertos ou alterados pelo homem.

Considerando que Bauhinia forficata é uma leguminosa arbórea, de rápido desenvolvimento, reproduçao precoce e frequentemente encontrada em ambientes instáveis, procurou-se avaliar neste trabalho alguns aspectos da biologia reprodutiva desta espécie, que permitissem uma melhor compreensao dos mecanismos que lhe garantem eficiência na ocupaçăo de ambientes tå diversos, especialmente na colonizaçao de áreas pertubadas.

Para elucidar alguns aspectos desta questao, 
o presente trabalho teve como objetivos:

a. estudar a ecologia da polinização, visando identificar o polinizador de Bauhinia forficata e seu comportamento;

b. avaliar o fluxo de pólen em relação a distância de transporte dos grãos de pólen e a sua distribuição entre as plantas dentro da população e, c. estimar a taxa de cruzamento da população de Bauhinia forficata estudada. 


\section{2- REVISAO BIBLI IGRAFICA}

\subsection{Caracteristicas gerais de Bauhinia forficata Link.}

Bauhinia forficata Link. é uma leguminosa que pertencia originalmente a familia Leguminosae, subfamilia Caesalpinoidea. Entretanto, segundo a classificaçao recente de CRONQUIST (1981), a espécie passa a pertencer a familia Caesalpiniaceae. A espécie está classificada na seçao Pauletia dentro do gênero Bauhinia e possui dois sinônimos cientificos, Bauhinia aculeata Vell. e Bauhinia brasiliensis Vog. (CORREA, 1984).

o gênero Bauhinia é pré-lineano e foi descrito em 1703 por Charles Plumier. A partir do século XIX começaram as divergências entre os taxonomistas, alguns adotando o conceito clássico e amplo de Bauhinia e outros fundando gêneros afins, que seriam reconhecidos mais tarde como seções do referido gênero (VAZ, 1979).

Finalmente, BENTHAN (1870) manteve o sentido amplo de Bauhinia, dividindo as espécies brasileiras em três seções. Uma delas, a seçao Pauletia (Cav.) DC, abrange as espécies nå escandentes arbustivas e arboreas, incluindo Bauhinia forficata. As outras duas seçoses 
Schnella e Tylotaea incluem espécies escandentes, lianas e arbustos, sendo que a maioria das espécies da seçao Tylotaea ocorre na Floresta Pluvial Tropical Amazônica, com forte endemismo ( $V A Z, 1979$ ).

Bauhinia forficata é conhecida popularmente como pata-de-vaca, pata-de-boi, unha-de-vaca, unha-de-boi e mororó, e se caracteriza como uma espécie arbórea de 6 a 9 metros de altura, chegando a medir, segundo KLEIN (1979), cerca de 15 metros no interior da floresta. Apresenta ramos frágeis ou pendulares; folhas de 8 a 10 centimetros de comprimento, divididas acima do meio, ovais ou lanceoladas e glabras nas duas faces, e possui acúleos que podem ser retos ou levemente curvos, conforme a descriçă de CORREA (1984) .

As inflorescências sao racemos simples. Suas flores sao hermafroditas, com cerca de 8 centimetros de comprimento, o cálice é gamossépalo, a corola dialipétala, com cinco pétalas brancas, dez estames, ovário súpero, linear, pubescente e estipitado. o fruto é um legume perfeito de 15 a 20 centimetros de comprimento e 2 a 3 centimetros de largura (CORREA, 1984).

A espécie Bauhinia forficata tem uma ampla distribuiça geográfica, ocorrendo nos estados de Minas Gerais, Rio de Janeiro, Sło Paulo (CORREA, 1984), Ceará (SCHACHT, 1992), Paraná, Santa Catarina e em outros paises 
da América Latina como Paraguai, Peru, Bolivia, Uruguai e Argentina (REZENDE, 1987).

Além de sua ampla distribuiçă geográfica, Bauhinia forficata ocorre em habitats bastante variados. Segundo levantamento fornecido pelo Prof. Ademir Reis (curador do Herbário "Barbosa Rodrigues" - HBR) a espécie ocorre nos estados de Santa Catarina e Paraná em áreas de capoeira (com individuos variando de 3 a 10 metros de altura), de floresta (individuos de 15 metros de altura), beiras de estradas e margens de rios (individuos de cerca de 2 até 8 metros de altura).

Adicionalmente, KOTCHETKOFF-HENRIQUES e JOLY (1988) demonstraram a ocorrência de Bauhinia forficata em encosta de forte declividade à margem do rio da Cachoeira (Itirapina, SP), onde a espécie está entre as mais frequentes. Esta área, apesar de nao apresentar perturbações antrópicas, está sujeita à constantes deslizamentos, o que restringe o número de espécies que ali conseguem se manter.

Quanto à biologia reprodutiva de Bauhinia forficata, alguns estudos importantes têm sido realizados enfocando especialmente os aspectos relacionados ás sementes e formas alternativas de propagaça.

No que se refere à germinaçao das sementes de Bauhinia forficata, BELTRATI e PAOLI (1989) avaliaram 
alguns aspectos relativos à luminosidade e permeabilidade do tegumento. Os resultados obtidos demonstraram que as sementes apresentam uma acentuada impermeabilidade à água, pois só germinaram após escarificaçao mecânica. Os autores também observaram indiferença ao fator luz, ocorrendo $100 \%$ de germinaçă no claro e $96 \%$ no escuro.

Com relaçå à dispersă de sementes de Bautinia forficata, BELTRATI \& PAOLI (1989) também verificaram que ocorre por autocoria, através da abertura do fruto em duas valvas lenhosas, que se enrolam hel icoidalmente.

Além da reproduçăo por sementes, Bauhinia forficata apresenta também propagaça vegetativa. Este tipo de reproduçå ocorre através de raizes gemiferas, que apresentam brotamentos até três 'metros de distância da planta mae, ou seja, do tronco principal (RODRIGUES et alii, 1990). Tal estudo foi realizado em uma floresta mesófila estacional semi-decidua, 5 meses após a incidência de fogo, evidenciando também a capacidade de sobrevivência da espécie mesmo em áreas frequentemente sujeitas à queimadas, podendo também representar uma estratégia alternativa para a espécie na colonizaçå de novas áreas.

Os aspectos mencionados anteriormente, tais como: capacidade de colonizaçå de áreas perturbadas (RODRIGUES et alli, 1990; HBR), sementes com dormência de 
tegumento devido à impermeabilidade à água e disperså autocórica (BELTRATI \& PAOLI, 1989), sugerem que a espécie possa. se enquadrar no conceito de pioneira antrópica descrito por KAGEYAMA et alli (1992), que sao "espécies nå tipicamente pioneiras na floresta primária e que fazem o papel de pioneiras na sucessao em áreas antrópicas".

Dados da fenologia das espécies arboreas do Bosque dos Jequitibás (Campinas, SP), obtidos por MATTHES (1980), demonstram que Bauhinia forficata apresentou floraça continua do inicio de agosto ao final de dezembro, apresentando frutos maduros desde o inicio de março até o final de novembro, no ano de 1978. Entretanto, no ano de 1977, a espécie apresentou floraçå somente nos meses de novembro e dezembro, e frutos maduros de junho a agosto, mostrando portanto uma variaça no padrao fenológico entre anos.

Em relaçåo à polinizaçăo, FAEGRI e PIJL (1979) ressaltam que as caracteristicas das flores, quando analisadas em conjunto, mostram que certas combinações produzem um determinado tipo de flor, ao qual está associado um mecanismo de polinizaçăo definido, caracterizando uma sindrome especifica.

Com base na literatura, verificou-se que certas caracteristicas das flores de Bauhinia forficata enquadram-se na sindrome de quiropterofilia (polinizaçăo 
por morcegos), tais como: flores brancas, grandes, expostas acima da folhagem e localizadas em inflorescências terminais do tipo racemo. Adicionalmente, FAEGRI \& PIJL (1979) acrescentam que as espécies do gênero Bauhinia apresentam flores com grandes quantidades de pólen, sendo esta outra caracteristica importante da sindrome de quiropterofilia.

* importante salientar ainda que várias espécies do gênero Bauhinia, que apresentam características florais semelhantes às descritas para Bauhinia forficata, são polinizadas por morcegos. Entre elas encontram-se Bauhinia benthamiana (RAMIREZ et alii, 1984), Bauhinia pauletia (HEITHAUS et alii, 1974), Bauhinia multinervia (HOKCHE \& RAMIREZ, 1990), Bauhinia rufa (SAZIMA \& SAZIMA, 1978) e Bauhinia bongardii (BERGALLO, 1990).

\subsection{Quiropterofilia en espécies Neotropicais}

Nas regiões tropicais, cerca de 750 espécies de plantas apresentam atributos florais que favorecem a polinização por mamíferos, sendo que os morcegos constituem - grupo de mamíferos mais importante como visitantes e polinizadores de flores. Entre as famílias de plantas das regiões neotropicais, adaptadas à polinização por morcegos (quiropterófilas), destacam-se as agaváceas, bignoniáceas, 
bombacáceas, bromeliáceas, cactáceas, gesneriáceas, leguminosas, musáceas e solanáceas (GRIBEL et alii, 1990).

De acordo com FAEGRI $e$ PIJL (1979), a Sindrome de Polinizaçåo pode ser entendida como o conjunto de caracteristicas morfológicas e fisiológicas das flores que estao relacionadas com os hábitos e a morfologia dos polinizadores.

Dentre as caracteristicas envolvidas na sindrome de quiropterofilia, GRIBEL et alii (1990) destacam que as flores das plantas polinizadas por morcegos apresentam antese crepuscular ou noturna em funçå do horário de atividade dos morcegos e, em algumas espécies as flores duram somente uma noite; a coloraçăo das flores está associada à orientaçăo dos morcegos à curta distância e, geralmente é branca ou creme e o odor, na maioria das espécies, é forte e desagradável ao olfato humano (semelhante à fermentaçå), sendo importante para que os morcegos possam localizar as flores a longa distancia.

A produçåo de néctar, em espécies quiropterófilas, geralmente é intensa se comparada à de flores polinizadas por insetos. BAKER (1978), ressalta que a quantidade de recompensa oferecida à um visitante floral depende também da concentraçăo de açúcares no néctar, sendo que esta varia consideravelmente de espécie para espécie e mostra uma clara relaçå com a natureza do polinizador 
predominante. 0 autor verificou concentrações de açúcar de cerca de $11 \%$ em espécies das familias Bombacaceae e Capparidaceae, ambas polinizadas por morcegos.

A quantidade de pólen nas espécies quiropterófilas é grande, apresentando geralmente muitos estames ou anteras aumentadas, sendo essa caracteristica evidenciada em Ceiba, Bautinia, Agave e outros gêneros, favorecendo a deposiçăo de volumosa carga de pólen no corpo do morcego, cujos pelos apresentam uma grande capacidade de transporte (FAEGRI \& PIJL, 1979; GRIBEL et alii, 1990).

Conforme GRIBEL et alii (1990), as flores sao expostas destacando-se da folhagem, o que favorece a aproximaçao do morcego em vôo. Algumas såo terminais, sobressaindo-se da copa, como no caso da dedaleira (Lafoensia), do pequi (Caryocar) e do imbiruçú (Pseudobombax). Outras sao cauliflórias, como no caso da cuieira (Crescentia) e outras sao flagerifolias, dispostas em longos pedúnculos.

Com relaçå à quiropterofilia, BAWA (1990) observa que exemplos de polinizaçao por morcegos podem ser encontrados em várias familias de plantas tropicais, mas sao particularmente comuns, ou bem estudados, em Bombacaceae, Passifloraceae, Mimosaceae e Caesalpiniaceae. 0 autor menciona que as interações planta-polinizador em florestas tropicais oferecem oportunidades únicas para 
elucidar vários problemas de interesse evolutivo e ecológico.

Em Bombacaceae, BAKER (1978) realizou um estudo em uma floresta tropical da Costa Rica, verificando que a espécie Ochroma pyramidale é polinizada por morcegos. Do mesmo modo, FISCHER et alii (1992) estudaram duas espécies de Bombacaceae na Floresta Tropical Atlântica, Pseudobombax grandiflorum e Bambacopsis calophylla, e verificaram que ambas sao polinizadas pelas mesmas espécies de morcegos, sendo que a fato destas duas espécies simpátricas apresentarem os mesmos. polinizadores pode ser explicado parcialmente pela floraçao assincrônica entre elas. Os autores discutem também que esta assincronia contribui para a manutença dos morcegos visitantes das flores na área de estudo ao longo de todo o ano, através da oferta continua de alimento.

Em Passifloraceae, SAZIMA \& SAZIMA (1978) observaram duas espécies de morcegos visitando as flores de Passiflora mucronata. As duas espécies de morcegos sao Glossophaga soricina e Carollia perspicilata e, apesar de ambas apresentarem tamanho compativel com as estruturas da flor, o papel de $C$. perspicilata como polinizador é questionado pelos autores devido à baixa frequência de visita desta espécie. Além disso, os autores observaram que G. soricina apresenta estratégia de "trap-liner". que 
favorece a fecundaçå cruzada. 0 modo de visita designado "trap-line", ou "linha-de-captura", implica que um determinado morcego visita as flores de plantas dispersas ao longo de sua rota noturna, durante o periodo de alimentaçåo (SAZIMA \& SAZIMA, 1975 ; SAZIMA \& SAZIMA, 1978).

Outro exemplo de quiropterofilia em Passifloraceae, na espécie Tetrastylis ovalis, foi observado por BUZATO \& FRANCO (1992).

As leguminosas, de um modo geral, especialmente as da familia Mimosaceae e Caesalpiniaceae, apresentam várias espécies quiropterófilas. Em Mimosaceae, CARVALHO (1960) relata a ocorrência de quiropterofilia. em Parkia gigantocarpa e PRANCE (1985) em Parkia pendula, na floresta tropical da Amazônia.

Em Caesalpiniaceae, além das espécies Hymeneae courbaril e H. stilbocarpa (CARVALHO, 1960; CRESTANA et alii, 1985), há um grande número de espécies pertencentes ao gênero Bauhinia que săo polinizadas por morcegos, como será visto à seguir.

\subsubsection{Quiropterofilia no gênero Bauhinia}

HOKCHE \& RAMIREZ (1990) avaliaram a ecologia da polinizaçao de sete espécies do gênero Bauhinia, 
pertencentes à duas seções: Pauletia, que inclui árvores, e Tylotaea, que inclui lianas, e verificaram que as espécies da seçå Tylotaea apresentam flores diurnas, pequenas, de cores bastante variadas e săo visitadas por várias espécies de insetos e pássaros, enquanto que as espécies da seçå Pauletia apresentam flores comparativamente grandes, brancas, com antese noturna e săo polinizadas por morcegos. Com base nestas observações, HOKCHE \& RAMIREZ (1990) concluem que os caracteres florais, bem como os animais envolvidos na polinizaçă, estå associados com as diferentes formas de vida das espécies (árvores ou lianas) e com as designações subgenéricas das espécies de Bauhinia estudadas. Deste modo, a concordância entre as caracteristicas reprodutivas e taxonomicas podem estar relacionadas aos padrões evolutivos ao nivel de seçao.

Duas espécies pertencentes à seçå Pauletia, Bauhinia pauletia e Bauhinia benthamiana sao quiropterófilas e autocompativeis, sendo ambas polinizadas pelas mesmas espécies de morcegos filostomideos, Phyllostomus discolor e Glossophaga soricina (HEITHAUS et alii, 1974 e RAMIREZ et alii, 1984).

Embora Bauhinia pauletia, estudada por HEITHAUS et alii (1974), seja auto-compativel, a autopolinizaçå das flores é improvável, pois há uma correlaçao entre a deposiça de pólen nos estigmas e a atividade dos 
morcesos, sugerindo que o movimento de pólen depende basicamente do transporte animal. Os autores citados descrevem duas estratégias na alimentaçao de néctar em Bauhinia pauletia. Em uma das estratégias, morcegos grandes, como Phyllostomus discolor, visitam em grupos, pousam e permanecem por um tempo relativamente longo esgotando todo o méctar das flores; o movimento de grupos de uma área para outra promove a fecundaçao cruzada. Em uma segunda estratégia, morcegos pequenos como Glossophaga soricina, realizam visitas solitárias e rápidas pairando em frente as flores, visitando uma serie de flores repetidamente e diminuindo a probabilidade de autogamia.

Una outra espécie pertencente ao gênero Bauhinia que também apresenta polinizaçao por morcegos é Bauhinia rufa, referida por SAZIMA \& SAZIMA (1978).

BERGALLO (1990) estudou a polinizaçå de Bauhinia bongardii na floresta amazonica e verificou que esta espécie também é polinizada por morcegos. Dentre as espécies de morcegos coletadas, apenas três Anoura geoffroyi, Choeroniscus minor e Lonchophylla 5p, apresentavam atributos morfológicos que favoreciam a tomada de néctar e pólen. Entretanto, outras duas espécies consideradas primariamente frugivoras, Carollia perspicillata e Sturnina lilium, foram observadas alimentando-se de néctar, o que levou o autor a crer que 
poderiam estar utilizando as flores de Bauhinia bongardii, especialmente pelo fato de essas duas espécies de morcego já terem sido observadas alimentando-se do néctar de outras espécies de plantas (HEITHAUS et alii, 1975; SAZIMA, 1976; SAZIMA \& SAZIMA, 1978).

$\mathrm{Na}$ literatura encontramos casos de quiropterofilia em espécies de diferentes familias botânicas, que ocorrem em diversos tipos de vegetaçao, variando desde florestas tropicais até cerrado. Neste sentido, os morcegos sao polinizadores que apresentam caracteristicas peculiares em relaçao ao comportamento de visita e à distância de vôo, que influenciam direta ou indiretamente as taxas de alogamia das espécies vegetais por eles polinizadas (HEITHAUS et alii, 1974; SAZIMA \& SAZIMA 1975; HEITHAUS \& FLEMING, 1978).

SAZIMA \& SAZIMA (1975) sugerem ainda que alguns morcegos antófilos podem adotar dois tipos distintos de estratégias alimentares; as visitas em grupo e a visita solitária em linhas-de-captura, sendo que estes dois tipos de visita parecem estar mais relacionados com a quantidade de alimento disponivel do que com a especializaçao alimentar dos visitantes. Mas, embora com comportamentos distintos, HEITHAUS et alii (1974) ressaltam que, tanto as visitas em grupos como as visitas solitárias em linhas-decaptura, promovem a fecundacao cruzada das plantas vi- 
sitadas.

\subsection{FLUXO DE POLEN}

o fluxo gênico têm sido amplamente discutido em relaçao à sua magnitude e influência sobre a estrutura genética das populaçães. Em plantas, a transferência de genes pode ocorrer tanto pelo movimento de gametas (pólen) quanto pelo movimento de organismos individuais (sementes, macrófitas, rizomas e estolães).

\subsubsection{Consideraçães gerais sobre fluxo gênico}

Fluxo gênico é definido por FUTUYMA (1992) como o intercruzamento entre individuos de uma populaçao local e imigrantes de outras populaçães, sendo que a taxa de fluxo gênico $m_{i j}$ de uma populaçao $j$ para uma populaçao $i$ é a proporçao de individuos que se reproduzem na populaçao $i$, que imigraram da populaçå $j$, naquela geraçao. 
0 mesmo autor descreve, também, quatro modelos de fluxo gênico, sendo eles: (i) o de "continenteilha", no qual ocorre um movimento de genes unidirecional de uma populaçå grande para outra menor e isolada; (ii) o modelo de "ilhas", no qual a migraçao ocorre ao acaso entre um grupo de pequenas populaçães; (iii) a de "alpondras" ("stepping-stone"), em que cada populaçă recebe migrantes somente de populaçães vizinhas e, (iv) a de "isolamento pela distância", no qual o fluxo gênico ocorre localmente entre os vizinhos, em uma populaçao de distribuiçao continua.

KAGEYAMA (1987) relata que o conhecimento da biologia reprodutiva em espécies arbóreas tropicais é de extrema importância, especialmente no que se refere a dispersåo de pólen e sementes, que apresentam interações bastante complexas, estando diretamente relacionadas ao fluxo gênico.

Além disto, FENSTER (1991b) ressalta que o fluxo gênico depende nå somente da distância de disperså dos genes, através dos vetores de dispersao de pólen e sementes, mas também das vantagens seletivas ou desvantagens que eles conferem aos individuos, pois o estabelecimento irá depender do vigor e da viabilidade do zigoto. 
A importância do fluxo gênico como força homogeneizadora entre populaçães de espécies foi amplamente discutida e questionada por EHRLICH \& RAVEN (1969) e GRANT $(1980)$

EHRLICH \& RAVEN (1969) argumentam que a seleçå é a força de coesă e disrupça mais importante na evoluçă, e que o regime seletivo em si determina qual influência o fluxo gênico (ou o isolamento) irá ter. Para sustentar essa argumentaça, os autores apresentam uma série de estudos mostrando que: (i) o fluxo gênico na natureza é muito mais restrito do que comumente se pensava,(ii) populações que estao completamente isoladas por longos periodos frequentemente mostram pequenas diferenciações, e (iii) populações que trocam genes livremente, mas estao sob diferentes regimes seletivos, podem mostrar diferenciações marcantes. 
GRANT (1980) questiona as considerações. feitas em relaçăo a restriçăo do fluxo gênico e considera a existência de algumas falhas no argumento de EHRLICH \& RAVEN (1969), pois eles enfatizam a dispersao à curta distância e desprezam os eventos de dispersao à longa distância. O autor enfatiza que há dois segmentos das curvas de distância de dispersao, que podem ser considerados como os mais significativos em termos de fluxo gênico. Estes segmentos sao chamados, pelo autor, de: (c) que corresponde à "cauda" da curva representando o registro das distâncias máximas de dispersao, e (d) que corresponde aos eventos desconhecidos e nå registrados de dispersao à longa distância, que vå além da área de estudo.

Adicionalmente, GRANT (1980) ressalta que EHRLICH \& RAVEN (1969) argumentam com base em dados de dispersao de uma única geraçao, nå considerando a dispersao através do tempo, sendo que as distâncias de dispersao sao acumulativas com o tempo, podendo resultar em longas distâncias de dispersao através dos anos. 
Além disso, MARTINS (1987) refere outra possibilidade de fluxo gênico no tempo, que pode ocorrer através da germinaçao diferencial das sementes armazenadas no solo, que constituem o banco de sementes. 0 autor citado ressalta que a ocorrência de dormência nas sementes de algumas espécies, levando à formaçao de um banco, gera uma sobreposiçao de geraçães sucessivas, podendo funcionar como um mecanismo de fluxo gênico no tempo.

Uma ampla revisao sobre fluxo gênico em plantas é apresentada por LEVIN \& KERSTER (1974), contendo um conjunto de informaçães sobre o comportamento de visita dos polinizadores e consequente fluxo de pólen em plantas zodfilas, fluxo de pólen em plantas anemófilas, dispersao de sementes e fluxo gênico. Neste estudo os autores citados distinguem as considerações entre "fluxo gênico potencial", que é considerado como a deposiça de pólen e sementes à partir de uma populaçao fonte, em funçao da distância, e o "fluxo gênico efetivo", que se refere a incidência de fertilizaçao (no caso de pólen) e ao estabelecimento de individuos reprodutivos (no caso de sementes), como uma funçao da distância da populaçao fonte. 
De acordo com LEVIN \& KERSTER (1974), podem haver grandes diferenças entre o fluxo gênico potencial e o efetivo. No entanto, as avaliaçães sobre o movimento de pólen e sementes fornecem valiosas informações para o entendimento da dispersao de genes na natureza, especialmente na ausência de marcadores genéticos apropriados e do conhecimento das frequências gênicas.

\subsubsection{Metodologias para estimar fluxo gênico}

- Atualmente, há uma série de metodologias diferentes para se estimar fluxo gênico. Entretanto, grande parte delas depende de algumas caracteristicas especificas que muitas vezes nå estao presentes na espécie de interesse, restringindo portanto sua aplicaçă. Com a utilizaçåo da técnica de eletroforese de isoenzimas, houve uma ampliaçăo das metodologias disponiveis, com a vantagem que os dados de isoenzimas podem ser obtidos para qualquer espécie.

Uma metodologia relativamente simples é comparar as frequências genotipicas de plantas jovens com as da geraçå adulta. Entretanto, variações na frequência genotipica podem ser devidas a vários fatores evolutivos, especialmente cruzamentos năo aleatórios e seleça. Portanto, se estes parâmetros nå forem quantificados, nå 
é possivel estimar, individualmente, o efeito do fluxo gênico sobre a composiçăo genética das populações (HAMRICK, $1987)$.

Outras metodologias bastante utilizadas para estimar fluxo gênico, em plantas, consistem em acompanhar o movimento dos vetores de dispersao (de pollen e sementes), das unidades de dispersao ou de genes marcadores (HAMRICK, 1987). 0 acompanhamento dos agentes de dispersao têm a vantagem que os movimentos podem ser seguidos em várias plantas dentro da populaçăo. Entretanto, o acompanhamento da movimentaçao destes componentes entre populações é bastante dificil de ser realizado.

Seguir o movimento real do pólen e da semente em vez de seus vetores é mais dificil, mas pode ser realizado pela marcaçao de pólen ou sementes com pós coloridos, elementos radioativos, ou medindo a deposiçao de pólen e sementes ao redor de individuos isolados (HAMRICK, 1987). Entretanto, esta metodologia só é válida para estimar fluxo gênico, se for possivel seguir estes componentes entre populações.

Marcadores genéticos têm sido utilizados com sucesso em populações estabelecidas artificialmente (HANDEL, 1982; HANDEL \& MISHKIN 1984), mas também existem limitações por ser dificil estabelecer, em populações artificiais, as mesmas caracteristicas das populações 
naturais (densidade, dispersao, estrutura de tamanho, polinizadores, etc.)

$$
\text { Recentemente, algumas metodologias, }
$$

utilizando dados de isoenzimas, têm sido desenvolvidas para medir o movimento de genes, entre elas encontra-se a de SLATKIN (1985), que apresenta uma estimativa do nivel médio de fluxo gênico, obtida através do número médio de migrantes transferidos entre populaçães locais ( $N m$ ); onde $N$ é o tamanho da populaçå e $m$ é a fraçao de imigrantes. Segundo o autor, o logaritmo de Nm está aproximadamente linearmente relacionado ao logaritmo da frequência média de alelos "raros" (alelos que aparecem somente em uma populaçå). Entretanto, esta metodologia tem sido pouco utilizada para se estimar fluxo gênico em plantas.

Uma outra metodologia que vem sendo utilizada recentemente é a análise de paternidade, que fornece uma descriça detalhada da estrutura reprodutiva da populaçao. A resoluçăo desta metodologia é dependente do número de locos polimórficos, do múmero de alelos por locos, da frequência destes alelos e do número de pais potenciais. Uma vez que o pai de cada progênie está identificado, os padrões de movimento de pólen dentro da área de estudo podem ser determinados, e a proporçao de pólen efetivamente oriundo de fora da área de estudo pode ser identificada (ELLSTRAND \& MARSHALL, 1985; GODT \& 
HAMRICK, 1993; BROYLES \& WYATT,1991). Além disto, DEVLIN \& ELLSTRAND (1990) colocam que a análise de paternidade tem, ainda, a vantagem de fornecer uma medida direta da transferência de gametas entre populações, fornecendo portanto estimativas das taxas de fluxo gênico.

\subsubsection{Dispersåo de pólen em espécies zoófilas}

Há uma série de estudos mostrando diferenças nas distâncias de dispersăo de pólen em populações naturais de espécies zodfilas, incluindo espécies com vetores de polinizaçao variados como borboletas, beija-flores e abelrias.

WEBB \& BAWA (1983) realizaram um estudo comparando a dispersao de pólen em duas espécies de plantas tropicais, Malvaviscus arboreus, polinizada por beijaflores, e Cnidoscolus urens polinizada por borboletas. As avaliaçães do fluxo de pólen foram realizadas utilizando pó fluorescente como marcador e as resultados obtidos demonstram que a frequência de pólen transferido diminui acentuadamente com o aumento da distância da planta marcada. A maior parte do pólen transportado, em $M$. arboreus, encontra-se entre 0 e 100 metros da árvore marcada; entretanto, foram observados eventos de dispersao até 225,5 metros de distância. Em C. urens, a distância 
média de dispersă foi de 8 metros, sendo a distância máxima observada de 31,2 metros.

CAMPBELL \& WASER (1989) avaliaram a variaçå no fluxo de pólen intra e interpopulacional também em Ipomopsis aggregata, comparando sua relaçă com a variaçå dos caracteres florais nesta espécie. Os autores utilizaram pó fluorescente como marcador e verificaram grandes variaçães no fluxo de pólen nas diferentes populaçães, relacionando estas variaçães, em parte, com a densidade das plantas, que era diferente entre as populações e, em parte, com as variaçães dos caracteres florais, especialmente o comprimento dos estames, que era variável entre plantas. A distância média de dispersăo de pó fluorescente verificada foi de até $a$ metros da planta marcada, apresentando uma maior frequência entre zero e un metro.

THOMSON \& THOMSON (1989) avaliaram a disperså de pólen por uma especie do gênero Bombus, em Erythronium grandiflorum (Liliaceae), utilizando o polimorfismo para a cor do pólen como marcador e verificando a contribuiça de cada visita do polinizador. Os autores registraram distâncias de dispersao de pólen de até 40 metros da planta marcada, com um pico entre 1,5 e 2,0 metros.

Em um estudo com populaçães experimentais, FENSTER (1991a) avaliou os dois componentes do fluxo gênico 
(pólen e sementes) em Chamaecrista fasciculata. A dispersao de pólen foi estimada medindo-se o vôo do polinizador e comparada com a dispersao de marcadores isoenzimáticos em um transecto experimental. A maioria dos vôos do polinizador e dos eventos de dispersao de genes na área experimental foram menores do que 1 metro.

EGUIARTE et alii (1993) mediram o movimento de pólen em Astrocaryum mexicanum, uma palmeira tropical polinizada por coledpteros, e verificaram uma distância média de dispersao de pólen de aproximadamente 20 metros.

BROYLES \& WYATT ( 1991 ) compararam o fluxo de pólen potencial através de observaçães do movimento dos polinizadores, que såo borboletas, com o fluxo de pólen efetivo, através do método de análise de exclusao de paternidade e observaram que a dispersao de pólen efetiva, de cerca de 4,33 metros, determinada pela análise de exclusao de paternidade, foi aproximadamente três vezes maior do que a média da dispersă de pólen, de 1,3 metros, obtida através da observaçao do polinizador. Estes resultados mostram que o simples acompanhamento do vôo do polinizador pode subestimar o fluxa de pólen real.

Outros trabalhos têm avaliado a influência da variaçao na densidade de plantas floridas sobre as distâncias de dispersåo de pólen. Um destes estudos foi realizado por LINHART \& FEINSINGER (1980) em populaçoes 
naturais de Mandevilla hirsuta e Justicia secunda, ambas polinizadas por beija-flores. 0 movimento de pólen foi acompanhado utilizando pó fluorescente e, em J. secunda, a dispersă de pólen foi estudada em densidades de floraçă variáveis, em dois locais diferentes. Os autores verificaram que as flores de $J$. secunda, no local em que a densidade era alta, foram visitadas mais frequentemente pelos polinizadores do que as flores em baixa densidade. Entretanto, houve uma maior distancia de dispersao de pólen nos locais onde a densidade era baixa, alcançando até 140 metros de distância da planta marcada, enquanto que em alta densidade, a disperså ocorria até aproximadamente 10 metros de distância.

Um outro estudo, com este enfoque, é apresentado por MURAWSKI (1987), que avaliou a fluxo de pólen, utilizando pó fluorescente como marcador, em Psiguria warscewiczii, uma espécie tropical polinizada por borboletas. Quando a densidade de flores era baixa, havia uma maior proporça de flores marcadas em distâncias intermediárias da planta fonte (100 a 250 metros). A densidade local de flores (medida em um raio de 50 metros a partir da planta marcada) representou aproximadamente $50 \%$ da variaçå observada na distância média de dispersă. Além disso, quando havia poucos recursos disponiveis (flores), muitas borboletas defendiam flores individuais 
durante toda a manha, nao deixando que outras borboletas as visitassem e, quando havia grande quantidade de recursos, as visitas das borboletas eram rápidas e observava-se um maior movimento entre plantas. 0 autor observou, ainda, distâncias de dispersao de pólen de mais de 600 metros da árvore marcada.

GODT \& HAMRICK (1993) avaliaram os padrães de movimento de pólen e fluxo gênico em Lathyrus latifolius, uma leguminosa perene, polinizada por uma espécie do gênero Bombus. A distância média do fluxo de pólen determinada variou de 11,6 a 13,3 metros entre locais e anos. Os autores observaram também que aumentos significativos nas taxas de fluxo gênico estavam associados com a diminuiça na densidade de plantas floridas.

Além das variações na densidade de plantas, há outras caracteristicas que podem influenciar as distâncias de disperså de pólen e, consequentemente, as taxas de fluxo gênico em plantas, como por exemplo os padrães fenológicos, a comportamento dos vetores de polinizaçå e os sistemas de cruzamento das espécies.

KAGEYAMA (1987) ressalta ainda que a distância de vôo do polinizador tem importantes consequências genéticas para as populaçães, pois existem grandes diferenças entre os animais polinizadores quanto ao hábito na visita das flores, o que tem relaçă direta com a 
distância efetiva que o pólen alcançaria na floresta.

\subsubsection{Metodologias para avaliar o fluxo de pólen}

Entre as metodologias disponiveis para avaliar as distâncias e curvas de disperså de pólen, uma das mais utilizadas é a marcaçå de pólen com corantes, especialmente com pó fluorescente (LINHART \& FEISINGER, 1980; WEBB \& BAWA, 1983; MURAWSKI, 1987; CAMPBELL \& WASER, 1989; EGUIARTE et alii, 1993).

Esta metodologia apresenta uma importante vantagem sobre o acompanhamento do movimento do polinizador, pois ela permite avaliar nå sd a distânçia a que a pólen está sendo transportado, mas também permite obter curvas de distribuiçă do transporte de pólen em várias distâncias dentro da populaçao.

A utilizaçăo de pó fluorescente como marcador foi analisada com detalhes por WASER \& PRICE (1982), em condições experimentais, comparando o transporte de pólen com a de pó fluorescente em Ipomopsis aggregata, uma espécie polinizada por beija-flor. Os autores verificaram que a dispersao tanto do pd fluorescente como de pólen apresentam os mesmos padrões, diminuindo na mesma proporçao durante a sequência de visitaçă. Os experimentos indicam que o pó fluorescente é um bom marcador para 
estudos de transferência de pólen.

EGUIARTE et alii (1993) utilizaram três métodos diferentes para estimar o fluxo de pólen em Astrocaryum mexicanum: (1) marcaçao com pó fluorescente, (2) distância minima entre-inflorescências masculinas e femininas ativas e (3) alelos raros como marcadores genéticos. Todas as três estimativas de dispersao de pólen apresentaram resultados similares, $\square$ que reforça os resultados obtidos por WASER \& PRICE (1982), mostrando que além do pó fluorescente ser um marcador com transporte análogo ao do pólen, ele também fornece resultados similares aos obtidos por outras metodologias.

2.4. Aspectos gerais do sistema reprodutivo de espécies arbóreas

0 sistema reprodutivo de espécies vegetais tem sido estudado através da obtença de estimativas da taxa de cruzamento, principalmente a partir de marcadores isoenzimáticos. As estimativas têm sido obtidas a partir de valores de coeficientes de endogamia ( $\hat{f})$, e sua relaçao com a taxa de cruzamento aparente ( $\hat{t} a$ ) (WEIR, 1990a; VENCOVSKY, 1992), ou através de estimativas de máxima verossimilhança (RITLAND \& JAIN, 1981; RITLAND \& EL-KASSABY, 1985). 
utilizaçao de marcadores isoenzimáticos, para obtençao das estimativas mencionadas, tem contribuido grandemente para o conhecimento da diversidade de sistemas de cruzamento. 0 autor mencionado refere que as variantes alozimicas possuem 3 vantagens distintas sobre os marcadores morfológicos para estudos do sistema reprodutivo de plantas: i. as alozimas så expressas codominantemente; ii. muitos locos isoenzimáticos så altamente polimórficos na maioria das populaçães e, iil. é pouco provável que as aloenzimas estejam sujeitas à fortes pressães seletivas.

Trabalhos mais recentes têm empregado, frequentemente, estimativas multiloco, especialmente para estudos em populaçães naturais de espécies arbóreas tropicais, como apresentado na Tabela 1.

Como pode ser verificado, a maioria das espécies estudadas apresentam taxas bastante altas, tendendo à alogamia. De acordo com MURAWSKI \& HAMRICK (1991), somente duas espécies que ocorrem em baixa densidade, Cavanillesia platanifolia e Ceiba pentandra, exibem claramente sistemas de cruzamento misto (Tabela 1).

MURAWSKI \& HAMRICK (1992a) demonstraram a importância da densidade de floraça sobre a taxa de cruzamento em Cavanillesia platanifolia, verificando taxas de cruzamentos mais baixas quando havia menor densidade de plantas floridas. Os autores observaram que algumas árvores 
TABELA 1. Estimativas multiloco das taxas de cruzamento $(\hat{t})$ em populaçães naturais de algumas espécies arbóreas tropicais. Piracicaba, SP, 1994

Espécie $\quad \hat{t m}\left(e r r o\right.$ padrao) $\begin{array}{c}\text { No de } \\ \text { locos Referência }\end{array}$

\begin{tabular}{|c|c|c|c|}
\hline $\begin{array}{l}\text { Bertholletia } \\
\text { excelsa }\end{array}$ & $0.849(0.033)$ & 02 & $\begin{array}{l}\text { o'Malley et } \\
\text { alii, } 1988\end{array}$ \\
\hline $\begin{array}{l}\text { Pithecel lobium } \\
\text { pedicel lare }\end{array}$ & $0.951(0.022)$ & 04 & $\begin{array}{l}\text { O'Malley \& } \\
\text { Bawa, } 1987\end{array}$ \\
\hline $\begin{array}{l}\text { Cavanillesia } \\
\text { platanifolia }\end{array}$ & $0.661(0.074)$ & 06 & $\begin{array}{l}\text { Murawski \& } \\
\text { Hamrick, 1992a }\end{array}$ \\
\hline $\begin{array}{l}\text { Beilschmedia } \\
\text { pendulata }\end{array}$ & $0.918(0.058)$ & 03 & $\begin{array}{l}\text { Murawski } \\
\text { et alii, } 1990\end{array}$ \\
\hline $\begin{array}{l}\text { Brosimum } \\
\text { alicastrum }\end{array}$ & $0.875(0.035)$ & 07 & $\begin{array}{l}\text { Murawski } \\
\text { et alii, } 1990\end{array}$ \\
\hline $\begin{array}{l}\text { Ceiba } \\
\text { pentandra }\end{array}$ & $0.689(0.032)$ & 06 & $\begin{array}{l}\text { Murawski \& } \\
\text { Hamrick, 1992b }\end{array}$ \\
\hline $\begin{array}{l}\text { Platypodium } \\
\text { elegans }\end{array}$ & $0.898(0.043)$ & 10 & $\begin{array}{l}\text { Murawski \& } \\
\text { Hamrick, } 1991\end{array}$ \\
\hline $\begin{array}{l}\text { Guararibea } \\
\text { asterolepis }\end{array}$ & $1.008(0.010)$ & 05 & $\begin{array}{l}\text { Murawski } \\
\text { et alii, } 1990\end{array}$ \\
\hline $\begin{array}{l}\text { Sorocea } \\
\text { affinis }\end{array}$ & $0.969(0.020)$ & 05 & $\begin{array}{l}\text { Murawski \& } \\
\text { Hamrick, } 1991\end{array}$ \\
\hline $\begin{array}{l}\text { Trichilia } \\
\text { tuberculata }\end{array}$ & $1.007(0.028)$ & 03 & $\begin{array}{l}\text { Murawski \& } \\
\text { Hamrick, } 1991\end{array}$ \\
\hline
\end{tabular}


geraram progênies inteiras resultantes de autofecundaçao, sendo que estas árvores estavam muito mais isoladas que as outras.

Por outro lado, 0.MALLEY \& BAWA (1987) observaram altas taxas de cruzamento $(0,951 \pm 0,021)$ em Pithecellobium pedicellare, apesar de esta também ser uma espécie que ocorre en baixa densidade, sugerindo que a espécie tem mecanismos de polinizaçao eficientes para promover a fecundaça cruzada à longas distâncias. Entretanto, os autores observaram heterogeneidade nas frequências alélicas do pólen e sugerem que esta populaçă encontra-se subestruturada.

En Bertholletia excelsa, uma árvore de dossel da Amazônia, 0’MALLEY et alii (1988) observaram que a espécie é predominantemente de fecundaçao cruzada, mas baixus niveis de endogamia podem ocorrer $(\hat{t m})=0,85 \pm$ $0,03)$.

AIDE (1986) demonstra que a distribuiçă das taxas de cruzamentos em plantas é fortemente influenciada pelo sistema de polinizaçăo. 0 autor ressalta que muitas das espécies polinizadas por animais mostram alta variaça interpopulacional, quando comparadas as espécies anemófilas, sugerindo que a grande imprevisibilidade dos animais como vetores de pólen é um dos fatores que leva a estas grandes variações. Isto pode ser evidenciado através 
de alguns estudos que mostram variações nas taxas de cruzamento em espécies polinizadas por animais, quando se tem diferentes densidades de plantas floridas (MURAWSKI \& HAMRICK, 1991; MURAWSKI et alii, 1990).

Alterações na densidade de floraçao podem levar a diferentes padrões de variaça nas taxas de cruzamento. Em Platypodium elegans e Sorocea affinis, MURAWSKI \& HAMRICK (1991) observaram taxas de cruzamento mais altas, quando havia uma reduçao na densidade de plantas floridas.

No entanto, em Cavanillesia platanifolia observou-se um padrao inverso, relatado por MURAWSKI et alii (1990), demonstrando que quanto menor a densidade, menor a taxa de cruzamento. Estes dados sugerem que diferentes espécies de polinizadores e de plantas apresentam comportamentos distintos em relaçao a um mesmo fenâmeno, resultando en diferentes consequências genéticas para as populações de plantas.

KAGEYAMA (1987) refere que muitas espécies tropicais apresentam assincronia de floraça, o que resulta em implicações sobre o tamanho efetivo das populações, pois este comportamento das plantas pode levar a cruzamentos preferenciais, resultando em uma restriçå do fluxo de pólen de forma continua na floresta. 
Um estudo que demonstra esta questao da assincronia foi realizado por MURAWSKI \& HAMRICK (1992b) com Ceiba pentandra. Ds autores observaram que a espécie tem um sistema de cruzamento misto, com uma estimativa de $\hat{t}$ de 0,689, conforme apresentado na Tabela 1 , e verificaram que a taxa de cruzamento entre os individuos amostrados nao foi aleatória, possivelmente devido à assincronia no tempo de floraçă, a cruzamentos preferenciais e a um comportamento de visita nao aleatório dos morcegos polinizadores. 


\title{
3- MATERIAL E METODDS
}

\subsection{Local e Populaçåo de estudo}

\begin{abstract}
o trabalino foi realizado em uma populaçao natural de Bauhinia forficata localizada em um remanescente de floresta mesófila semi-decidua, na Estaçao Ecológica de Ibicatu. A área está sob administraça do Instituto Florestal, da Secretaria do Meio Ambiente do Estado de Så Paulo, e foi denominada de Reserva Estadual de Ibicatu, criada através do Decreto No 33.261 de 29 de julho de 1958. Atualmente é designada de Estaçå Ecológica de Ibicatu, criada pelo Decreto No 26.890 de 12 de março de 1987. A estaçăo possui uma área de 76,4 ha., com altitude média de 500 metros entre as coordenadas $22^{\circ} 46^{\prime}$ a $22^{\circ} 47^{\circ}$ latitude sul e 47043'a 47045' longitude oeste e localiza-se no municipio de Piracicaba, Estado de Så Paulo.
\end{abstract}

A estaçao representa um remanescente de floresta mesófila e encontra-se, atualmente, cercada por plantações de cana-de-açúcar e pastagens.

A amostra de populaça estudada encontra-se distribuida na margem do fragmento, ocupando uma área de 
$2.500 \mathrm{~m}^{2}$, sendo constituida de aproximadamente 30 individuos em estádio reprodutivo, variando de 1,5 a 8,0 metros de altura.

Foram coletadas amostras foliares e sementes de 13 indivíduos da população, que apresentavam número de frutos suficiente para estimar a taxa de cruzamento, através de marcadores isoenzimáticos. Durante a fenofase de floração, no período de novembro de 1992 a fevereiro de 1993, foram realizadas observações e testes para o estudo da ecologia da polinização, bem como marcações com pó fluorescente para avaliação do fluxo de pólen, sendo utilizados nestas etapas todos os individuos que apresentavam flores.

\subsection{Avaliação da Ecologia da Polinização}

O estudo da biologia floral de Bauhinia forficata foi realizado no período de floração da espécie, de novembro de 1992 a fevereiro de 1993.

Durante o estudo, foram realizadas observações sobre a biologia e a morfologia da flor, em vários estádios do seu desenvolvimento. Dados sobre o horário e sequência da antese, receptividade do estigma, disponibilidade e viabilidade do pólen, duração da flor, volume e concentração do néctar foram registrados. Características das flores como odor, 
coloração, tipo de alimento oferecido e sua localização foram também anotadas.

A receptividade do estigma foi testada com água oxigenada (ZEISLER, 1938) e com Sudam III glicerinado (JOHANSEN, ' 1940), em flores coletadas durante a noite (flores recém abertas) e no dia seguinte à sua abertura (flores em início de senescência), para avaliar a extensão do período de receptividade.

A viabilidade dos grãos de pólen foi avaliada utilizando-se o corante carmin acético, conforme descrito por RADFORD et alii (1974), que cora de vermelho os grãos de pólen viáveis, sendo as contagens efetuadas em lâminas de vidro analisadas em microscópio óptico.

As medidas de viabilidade do pólen, volume e concentração do néctar foram obtidas de amostras de 20 flores e os respectivos desvios padrões foram calculados. A concentrugão de açúcares no néctar foi medida com auxílio de um refratômetro de bolso e, para tal, foram isoladas flores $\epsilon_{\text {: }}$ estádio pré-antese de vários indivíduos, no dia anterior is sua abertura, sendo as medidas realizadas após a antese. 0 volume de néctar acumulado por flor foi medido, ilizando-se capilares de $10 \mathrm{~cm}$ de comprimento por $1 \mathrm{~mm}$ de i: ismetro.

A presença de osmóforos foi verificada 
utilizando-se vermelho neutro (VOGEL, 1963), sendo as flores mergulhadas na solução por aproximadamente quinze minutos e, em seguida, lavadas em água destilada para verificar se alguma região da flor permanecia corada, indicando assim a localização dos osmóforos.

As observações sobre os visitantes florais de Bauhinia forficata foram realizadas em todos os períodos do dia, perfazendo um total de 50 horas, distribuidas nos meses de janeiro e fevereiro de 1993. O estudo sobre o comportamento dos visitantes foi realizado a partir de observações visuais diretas no período diurno e com auxilio de lanternas elétricas, cobertas com filtros vermelhos, durante o período noturno.

Foram observados o horário, a duração, o comportamento de visita, o número de flores visitadas e o tipo de recurso coletado pelos visitantes.

Para a coleta dos visitantes, foram utilizadas três estratégias diferentes : (i) para coleta de exemplares de Hymenoptera e Lepidoptera, que visitavam as flores no período diurno, foi utilizada rede entomológica manual; (ii) para a coleta dos esfingideos foram utilizadas armadilhas apropriadas conforme descrito por De VRIES (1987), que eram presas em ramos floridos de várias árvores e examinadas de hora em hora e, (iii) para coleta dos morcegos foram utilizadas duas redes de neblina "mist 
nest", de 12 metros de comprimento por 3 metros de altura cada uma, armadas em quatro noites durante o período de observação de visitantes, na altura da copa das árvores.

Os visitantes capturados foram examinados em estereomicroscópio, para verificar a presença e o local de deposição do pólen; e em microscópio de fluorescência, para verificar a presença de particulas de pó fluorescente em estruturas do corpo das espécies coletadas. Após essas análises, os exemplares foram fixados para identificação, sendo que os insetos foram fixados a seco e os morcegos em formol 70\%. Os exemplares de Lepidoptera (diurnos) e Chiroptera foram enviados à especialistas do Departamento de Zoologia, do Instituto de Biologia, da Universidade Estadual de Campinas, para identificação. Os exemplares de Lepidoptera (noturnos) e Hymenoptera foram enviados à especialistas do Departamento de Entomologia, da Escola Superior de Agricultura "Luiz de Queiroz", da Universidade de São Paulo.

\subsection{Medidas do fluxo de pólen}

A análise do fluxo de pólen em Bauhinia forficata foi realizada em plantas floridas, localizadas na borda (margem) do remanescente de vegetação e distribuidas ao longo de uma área de aproximadamente 250 
metros de comprimento por 10 metros de largura.

As marcações para medir o fluxo de pólen foram realizadas no período de dezembro de 1992 a fevereiro de 1993 e basearam-se na metodologia descrita por WASER \& PRICE (1982), utilizando-se pó fluorescente como marcador, obtido da Hércules (Richmond, Califórnia).

$$
\text { Para determinar a distância e a quantidade }
$$

de pólen transportada entre as plantas de Bauhinia forficata, foram realizadas marcações logo após a abertura das flores (entre 20:00 e 23:00 horas) em uma ou mais árvores próximas, procurando-se marcar um mínimo de cinquenta flores por noite. As marcações foram feitas depositando-se o pó fluorescente sobre as anteras deiscentes com o auxilio de um pincel fino, sendo que as árvores marcadas eram consideradas como "ponto zero", à partir do qual eram realizadas as coletas em seis classes de distância.

As coletas das flores foram realizadas no dia seguinte à marcação, no período da manhã. As distâncias e o número de flores previstas para coleta, a cada avaliação são apresentadas na Tabela 2. 0 critério utilizado foi o de se aumentar o número de árvores e de flores coletadas, à medida que aumentava a distância da árvore marcada, visando a obtenção de uma amostragem satisfatória nas várias classes de distância. 
TABELA 2. Protocolo geral das distâncias e número de flores por coleta para o rastreamento de pólen marcado em Bauhinia forficata. Piracicaba, SP, 1994

\begin{tabular}{cccc}
\hline $\begin{array}{c}\text { Distância(m) } \\
\text { da árvore } \\
\text { marcada }\end{array}$ & $\begin{array}{c}\text { Número de } \\
\text { árvores } \\
\text { por coleta }\end{array}$ & $\begin{array}{c}\text { Número de } \\
\text { flores } \\
\text { por árvore }\end{array}$ & $\begin{array}{c}\text { Número } \\
\text { total } \\
\text { de flores }\end{array}$ \\
\hline & & & \\
$0-10$ & 2 & 10 & 20 \\
$10-20$ & 2 & 10 & 20 \\
$20-40$ & 2 & 10 & 20 \\
$40-80$ & 3 & 10 & 30 \\
$80-120$ & 3 & 10 & 30 \\
$120-220$ & 5 & 10 & 50 \\
\hline
\end{tabular}

As flores coletadas tiveram seus estigmas retirados, dispostos em lâminas de vidro e analisados em microscópio de fluorescência do Departamento de Genética, da Escola Superior de Agricultura "Luiz de Queiroz", da Universidade de São Paulo. Esta análise permitiu verificar a presença e quantidade de grãos de pólen, marcados com pó fluorescente, sobre os estigmas das flores coletadas nas várias classes de distância. Os grãos marcados emitem brilho intenso sob a luz ultravioleta do microscópio, permitindo facilmente sua identificação e contagem. 
Após as contagens, foram determinadas a porcentagem de estigmas e flores que receberam pólen do individuo marcado, assim como avaliado o número médio de grãos de pólen marcados por estigma nas diversas classes de distância, fornecendo assim informações sobre - raio de ação do polinizador.

\subsection{Análises eletroforéticas}

a. Tecidos das plantas para eletroforese de isoenzimas

As análises de eletroforese de isoenzimas foram realizadas utilizando-se tecidos foliares de plântulas e de individuos adultos. Para as análises das progênies, foram coletadas folhas intactas de plantas com nove meses a partir da semeadura, cultivadas em viveiro com $50 \%$ de sombrite, sendo que os tecidos eram imediatamente submetidos à extração e aos procedimentos de eletroforese, para evitar alterações ou degradação das enzimas nos mesmos.

As folhas das plantas adultas (genitoras), coletadas na área experimental, foram imediatamente trazidas para o laboratório e, após terem sido 
realizadas as extrações, as amostras foram devidamente acondicionadas para as análises posteriores.

b. Escolha dos sistemas isoenzimáticos

\begin{abstract}
Foram realizadas análises preliminares para os 12 sistemas isoenzimáticos listados a seguir acompanhados de seus respectivos códigos (E.C.) da "Enzyme Commission of the International Union of Biochemistry (1976)" :
\end{abstract}

Alfa-Esterase (Alfa-EST- E.C.3.1.1.1),

Beta-Esterase (Beta-EST-E.C.3.1.1.1),

Glutamato Desidrogenase, (GDH-E.C.1.1.1.49),

Leucina Aminopeptidase (LAP-E.C.3.4.11.1),

Shiquimato Desidrogenase (SKDH-E.C.1.1.1.25),

Malato Desidrogenase (MDH-E.C.-1.1.1.37),

Isocitrato Desidrogenase (IDH-E.C.1.1.1.42),

Fosfatase Ácida (ACP-3.1.3.2),

Álcool desidrogenase (ADH-E.C.1.1.1.1),

Peroxidase (PER-E.C.1.11.1.7),

Fosfoglicose Isomerase (PGI-E.C.5.3.1.9) e

6-Fosfogliconato Desidrogenase (6PGD-E.C.1.1.1.44).

Com base nos resultados obtidos nos testes preliminares, foram escolhidos os sistemas enzimáticos IDH 
e Alfa-EST, que apresentaram boa resolução para os tecidos de limbos foliares de plantas adultas (genitoras) e de plantas de 9 meses de idade (progênies).

\section{c. Rxtração dé isoenzimas}

Para a extração de isoenzimas foram utilizadas amostras de aproximadamente $20 \mathrm{mg}$ de tecido de limbo foliar, maceradas com aproximadamente $07 \mathrm{mg}$ de PVPP (Polivinil Polipirrolidona), $10 \mathrm{mg}$ de areia lavada (areia peneirada, lavada com ácido sulfúrico e livre de limalhas de ferro) e 100 microlitros de solução de extração no 01 de ALFENAS et alii (1991).

Os tecidos foram macerados, com o auxílio de um bastão de vidro, sobre placas de porcelana previamente resfriadas, mantidas durante a extração sobre barras de gelo para evitar a desnaturação das isoenzimas.

Os extratos de cada amostra eram absorvidos em pedaços de papel filtro (papel whatman n०3), com dimensões de $6 \mathrm{~mm} \times 10 \mathrm{~mm}$, que eram colocados lado a lado no gel. Em cada gel eram colocadas 20 amostras e mais 2 pedaços de papel filtro contendo solução azul de bromofenol a $0,1 \%$, em cada uma das extremidades, para marcar a linha de frente durante a migração. 


\section{d. Procedimentos de eletroforese}

o meio suporte utilizado para a eletroforese foi 0 gel de penetrose de milho, com concentração de 13\%. 0 sistema tampão gel / eletrodo utilizado para os 2 sistemas enzimáticos (IDH e Alfa-EST) foi o Tris-Citrato (TC), conforme descrito por SOLTIS et alii (1983). Para preparar o tampão para o eletrodo utilizou-se: Trizma base $(0,223 \mathrm{M})$ e ácido cítrico $(0,086 \mathrm{M})$, sendo o pH ajustado em 7,5. O tampão do gel foi preparado através da diluição a $3,5 \%$ do tampão do eletrodo. A técnica de eletroforese utilizada foi a de migração das isoenzimas em géis horizontais, mantidos durante toda a corrida em refrigerador à $4{ }^{\circ} \mathrm{C}$.

Para a corrida eletroforética, utilizou-se $20 \mathrm{~mA}$ de corrente constante e voltagem de $130 \mathrm{~V}$ durante 30 minutos, após os quais a corrente era aumentada para $45 \mathrm{~mA}$ é a voltagem para 250 V. Após 45 minutos do início da corrida as amostras de papéis de filtro eram retiradas. O tempo de corrida era de aproximadamente 6 horas, quando o marcador de bromofenol atingia em torno de 8,0 a $9,0 \mathrm{~cm}$ de migração.

Completada a migração, os géis eram cortados em quatro fatias de $2,5 \mathrm{~mm}$ de espessura cada uma e preparados para a coloracão. A primeira e a última fatias eram desprezadas, a segunda era utilizada para a coloração 
da Isocitrato desidrogenase (IDH) e a terceira para a coloração da Alfa-Esterase (Alfa-EST).

Para a revelação das isoenzimas, foram utilizados os seguintes protocolos:

a) Alfa-EST (Alfa-esterase)- Modificado a partir de SOLTIS et al. (1983)

Solução "A"

- Alfa-Naftil Acetato (40 mg/ml de acetona 50\%) 01ml

- Tampão fosfato de sódio 0,5M, pH 6,0 40ml

Solução "B"

- Fast Garnet GBC (salt) (30 mg/ml de n-propanol) 02ml

- Tampão fosfato de sódio 0,5M, pH 6,0 10ml

Procedimento: 0 gel era imerso na solução "A" por 20 minutos e em seguida era adicionada a solução "B"; tempo de revelação 50 minutos; temperatura: $37^{\circ} \mathrm{C}$.

b) IDH (Isocitrato desidrogenase)- Modificado a partir de STUBER et al. (1988)

- DL-Ácido Isocitrico, $\mathrm{Na} 3$

100mg

- MTT $10 \mathrm{mg}$

- NADP+ $10 \mathrm{mg}$

- PMS $01 \mathrm{mg}$

- $\mathrm{MgCl} 2$ $10 \mathrm{mg}$

- Tampão Tris-Hcl 0,1M, pH 8,0 $50 \mathrm{ml}$

Procedimento: Os reagentes eram diluídos no tampão e 08 géis eram imersos nesta solução e incubados no escuro; tempo de revelação: 40 minutos; temperatura: $37 \circ \mathrm{C}$. 
e. Leitura dos zimogramas

A leitura dos zimogramas ocorria logo após a revelação das isoenzimas, quando as bandas eram desenhadas em filme plástico com canetas de retroprojetor, guardando suas dimensões originais. Também eram desenhadas as marcas de migração do marcador de bromofenol, para comparações relativas entre os géis e obtenção dos respectivos valores de Rf, conforme citado por FERRAZ et alii (1994). Sendo também empregado o parâmetro RM (migração relativa), conforme descrito por CHELIAK \& PITTEL (1984), que considera como banda padrão - alelo mais frequente na população, que recebe o valor 100, sendo a migração relativa de todos os outros alelos, de cada loco, calculada em relação à banda padrão. Logo após desenhados, os géis eram fotografados, permitindo com isso a disponibilidade de reproduções fiéis dos zimogramas, para conferir eventuais dúvidas no momento da interpretação.

\subsection{Análise dos dados isoenzimáticos}

Para se avaliar o sistema reprodutivo de Bauhinia forficata, foram obtidas as frequências de cada um dos quinze alelos encontrados na população estudada e, a 
partir delas, foram obtidas as frequências genotipicas esperadas para realizar o teste de Qui-quadrado para os desvios do equilíbrio de Hardy-Weinberg. Para o teste do Qui-quadrado foi utilizado o programa Biosys-1 desenvolvido por SWOFFORD \& SELANDER (1989), que agrupa as frequências esperadas dos alelos menos frequentes, ficando os genótipos de cada loco, reunidos em três classes: i. homozigotos para - alelo mais comum, ii. heterozigotos compostos pelo alelo mais comum e os outros alelos e iil. todos os outros genótipos. O valor do qui-quadrado resultante é usado com um grau de liberdade em cada loco.

A partir dos resultados obtidos com o teste do qui-quadrado para os desvios do Equilibrio de HardyWeinberg, procedeu-se às estimativas da taxa de cruzamento de Bauhinia forficata. Estas estimativas foram obtidas utilizando-se duas metodologias distintas. A primeira baseia-se na análise de variância das frequências gênicas, para cada um dos alelos presentes na população (WEIR, 1990a; VENCOVSKY, 1992), sendo válida apenas se a população estiver em equilibrio de endogamia, e foi denominada taxa de cruzamento aparente $(\hat{t a}) ;$ e a segunda, se baseia na utilização de estimadores de máxima verossimilhança, conforme proposto por RITLAND \& JAIN (1981), através do programa multiloco desenvolvido por RITLAND (1990), denominada taxa de cruzamento multiloco $\left(\hat{t}_{m}\right)$. 


\subsubsection{Bstimativas da taxa de cruzamento aparente ( $\hat{\mathbf{t}} \mathrm{a})$}

A análise de variância das frequências gênicas, para cada um dos alelos presentes na população em estudo, permite estimar a taxa aparente de fertilização cruzada ( $\left.\hat{t}_{a}\right)$, que pode ser obtida através da estimativa de $\hat{f}$ se a população em estudo estiver em Equilíbrio de Wright (equilibrio com endocruzamento). Para tanto, VENCOVSKY (1992) sugere que é conveniente testar a validade da suposição do Equilibrio de Wright, antes de se estimar a taxa de cruzamento com base no coeficiente de endogamia.

a) Qui-quadrado para os desvios de equilíbrio de endogamia

0 coeficiente de endogamia $(\hat{f})$ para a população foi estimado a partir das frequências genotípicas esperadas (He) e observadas (Ho) de heterozigotos, conforme demonstrado inicialmente por WRIGHT (1922) e por WEIR (1990a), através da seguinte expressão:

$$
\hat{f}=(\hat{H e}-\tilde{H o}) / \hat{H e}
$$

onde:

$\hat{\mathrm{H}} \mathrm{e}=1-\Sigma \mathrm{Pu}^{2}$, sendo $\mathrm{Pu}^{2}$ a frequência esperada de homozigotos para o alelo u,

Hैo $=1-\Sigma$ Puu, sendo Puu a frequência observada de homozigotos para o alelo u. 
O valor de $\hat{f}$ obtido através desta expressão foi utilizado para se estimar as frequências genotipicas esperadas, usadas para se testar os desvios do equilibrio de Endogamia de Wright, através do teste de Qui-quadrado. Os genótipos com frequências próximas de um foram agrupados em classes, sendo possivel utilizar apenas os locos que apresentavam número de alelos suficiente para permitir este agrupamento.

\section{b) Análise de variância}

A estimativa da taxa aparente de fertilização cruzada ( $\hat{t} a)$ foi obtida através da análise de variância para cada alelo identificado na população, conforme proposto por WEIR (1990a) e por VENCOVSKY (1992).

Este procedimento foi utilizado para estimar os seguintes parâmetros genéticos: variância entre famílias $\left(\sigma_{F}^{2}\right)$, variância entre indivíduos/famílias $\left(\sigma_{I}^{2}\right)$, variância entre genes/indivíduos/famílias $\left(\sigma_{\mathrm{d}}^{2}\right)$, variância total $\left(\sigma_{\mathrm{r}}^{2}\right)$, grau de parentesco dentro de famílias $\left(\hat{\theta}_{1}\right)$, coeficiente de endogamia dentro da população $(\hat{f})$ e taxa de cruzamento aparente $(\hat{t} a)$.

As análises foram feitas em esquema hierárquico desbalanceado e o modelo matemático utilizado, com dois niveis de hierarquia, foi:

$$
Y_{1 \jmath y x}=m+f_{1}+h_{\jmath}(1)+g_{l x}(1 y)
$$


onde : $Y_{1 \jmath k}$ é a frequência do gene $k$, dentro do indivíduo $j$, da familia $i$;

m é a média geral;

$f_{1}$ é o efeito da família $i, \operatorname{com} i=1,2, \ldots, 1$;

hJ(1) é o efeito do individuo $j$, dentro da família $i, \operatorname{com} j=1,2, \ldots, \mathrm{m}_{1}$;

$g_{k}(1 j)$ é o efeito do gene $k$, dentro do indivíduo $j$, na familia $i$ com $k=1,2, \ldots$ nıy.

o esquema da análise de variância é demonstrado na Tabela 3.

TABELA 3. Análise de variância para um alelo de um dado loco em um modelo hierárquico desbalanceado, contendo como fontes de variação famílias (F), indivíduos $(I / F)$ e' genes $(G / I / F)$, conforme VENCOVSKY (1992). Piracicaba, SP, 1994

\begin{tabular}{|c|c|c|c|c|c|}
\hline F. V. & & GL & SQ & $O M$ & $E C O M D$ \\
\hline Familias & & $1-1$ & $\mathrm{SQ}_{F}$ & $O M_{F}$ & $\sigma_{G}^{2}+2 \sigma_{I}^{2}+K \sigma_{F}^{2}$ \\
\hline Individuos & & $\sum_{1=1}^{1} m_{1}-1$ & $S Q_{I}$ & $O M_{I}$ & $\sigma_{a}^{2}+2 \sigma_{1}^{2}$ \\
\hline Genes & $\sum_{i=1}^{1}$ & $\sum_{j=1}^{m_{i}} n_{1 j}-\sum_{1=1}^{1} m_{1}$ & $\mathrm{SQ}_{\mathrm{o}}$ & $\mathrm{M}_{\mathrm{o}}$ & $\sigma_{0}^{2}$ \\
\hline
\end{tabular}


A análise de variância foi realizada, considerando 1 famílias na população, $m$ indivíduos por progênie e $n=2$ genes por loco em cada planta, sendo que o indice $\mathrm{K}$ foi obtido através da média harmônica do número de individuos das progênies vezes o número de genes por loco, utilizando o programa PROC NESTED (SAS Institute, 1985), conforme recomendado por WEIR (1990b).

\section{c) Componentes de vaxiância}

As estimativas dos componentes da variância foram obtidas conforme a metodologia apresentada por WEIR (1990a), a partir dos seguintes desdobramentos:

$$
\begin{aligned}
& \hat{\sigma}_{G}^{2}=O M_{O}, \\
& \hat{\sigma}_{I}^{2}=\left(O M_{I}-O M_{O}\right) / Z, \\
& \hat{\sigma}_{F}^{2}=\left(O M_{F}-O M_{I}\right) / K, \\
& \partial_{T}^{2}=\sigma_{G}^{2}+\sigma_{I}^{2}+\sigma_{F}^{2} .
\end{aligned}
$$

Os coeficientes de co-ancestralidade $\left(\hat{\theta}_{1}\right)$, de endogamia dentro da população $(\hat{f})$ e taxa aparente de cruzamento ( $\hat{t} a)$, para cada alelo, foram obtidos através de:

$$
\begin{aligned}
& \hat{\theta}_{1}=\sigma_{F}^{2}-\sigma_{T}^{2}, \\
& \hat{f}=1-\left(\sigma_{\sigma}^{2}-\sigma_{T}^{2}\right), \\
& \hat{t}=(1-\hat{f})-(1+\hat{f}) .
\end{aligned}
$$


Sendo que:

$$
\begin{aligned}
\hat{\sigma}_{a}^{2} & =\hat{p}(1-\hat{p})(1-\hat{f}) . \\
\hat{\sigma}^{2} & =\hat{p}(1-\hat{p})\left(\hat{f}-\hat{\theta_{1}}\right) . \\
\hat{\sigma}^{2} & =\hat{p}(1-\hat{p}) \hat{\theta_{1}} . \\
\hat{\sigma}_{T}^{2} & =\hat{p}(1-\hat{p}) .
\end{aligned}
$$

Considerando a existência de a alelos na população e que para cada um deles é realizada uma análise de variância, teremos $\Sigma$ a análises. Pressupondo que os alelos são seletivamente neutros, procede-se uma análise conjunta reunindo todos os alelos, obtendo-se uma média dos quadrados médios por alelo e reunindo-se os locos obtendose uma média dos quadrados médios por loco, como segue :

$$
\begin{aligned}
& Q M_{F}=\left(\Sigma S Q_{F}\right)-\left(\Sigma G L_{F}\right), \\
& Q M_{I}=\left(\Sigma S Q_{\mathbf{I}}\right)-\left(\Sigma G L_{\mathbf{I}}\right) . \\
& Q M_{\mathbf{G}}=\left(\Sigma S Q_{\mathbf{Q}}\right)-\left(\Sigma G L_{\mathbf{Q}}\right) .
\end{aligned}
$$

d) Obtenção de $\hat{\text { ta }}$

Considerando a existência de Equilíbrio de Endogamia na população de Bauhinia forficata estudada, a taxa de cruzamento aparente $\left(\hat{t}_{a}\right)$ pode ser estimada, segundo WEIR (1990a) e VENCOVSKY (1992), através de:

$$
\hat{t_{a}}=(1-\hat{f})-(1+\hat{f})
$$


3.5.2. Estimativa multiloco da taxa de cruzamento $\left(\hat{t}_{m}\right)$

o modelo de cruzamento misto, proposto por RITLAND \& JAIN (1981), foi utilizado para estimar a taxa de cruzamento multiloco da população ( $\hat{t} \mathrm{~m})$; as taxas de cruzamento dos locos individuais $(\hat{t} s)$ e as frequências alélicas do pólen e do óvulo.

Para obtenção destas estimativas foi utilizado o programa multiloco de cruzamento misto desenvolvido por RITLAND (1990). Este programa testa, também, se as frequências genotipicas da progênie apresentam, desvios significativos do esperado no modelo, através de um teste de qui-quadrado de adequação ao modelo, que é usado com um grau de liberdade para um loco dialélico e com nove graus de liberdade para um loco trialélico.

O erro padrão da estimativa t̂́m foi calculado pelo método "bootstrap", sendo cada estimativa do erro padrão baseada em 100 "bootstraps". 


\section{1- RESULTADOS E DISCUSSAO}

4.1. Avaliação da ecologia da polinização

\subsubsection{Análise da biologia floral}

A morfologia da flor nos vários estádios de seu desenvolvimento é apresentada esquematicamente na Figura 1. O botão pré-antese é ilustrado na Figura 1a, sendo que a partir desta fase inicia-se a antese da flor. $\mathrm{Na}$ Figura 1b pode-se ver o início da abertura da flor, que ocorre entre as 18:30 e 21:00 hs., e inicia-se com uma fenda longitudinal no cálice, que leva cerca de uma hora para se completar, quando então ocorre a exposição das pétalas que começam a se abrir da base para o ápice. Entre 20:00 e 22:30 hs., trinta minutos após a abertura do cálice, todas as estruturas da flor apresentam-se livres e eretas, como ilustrado na Figura 1c. 

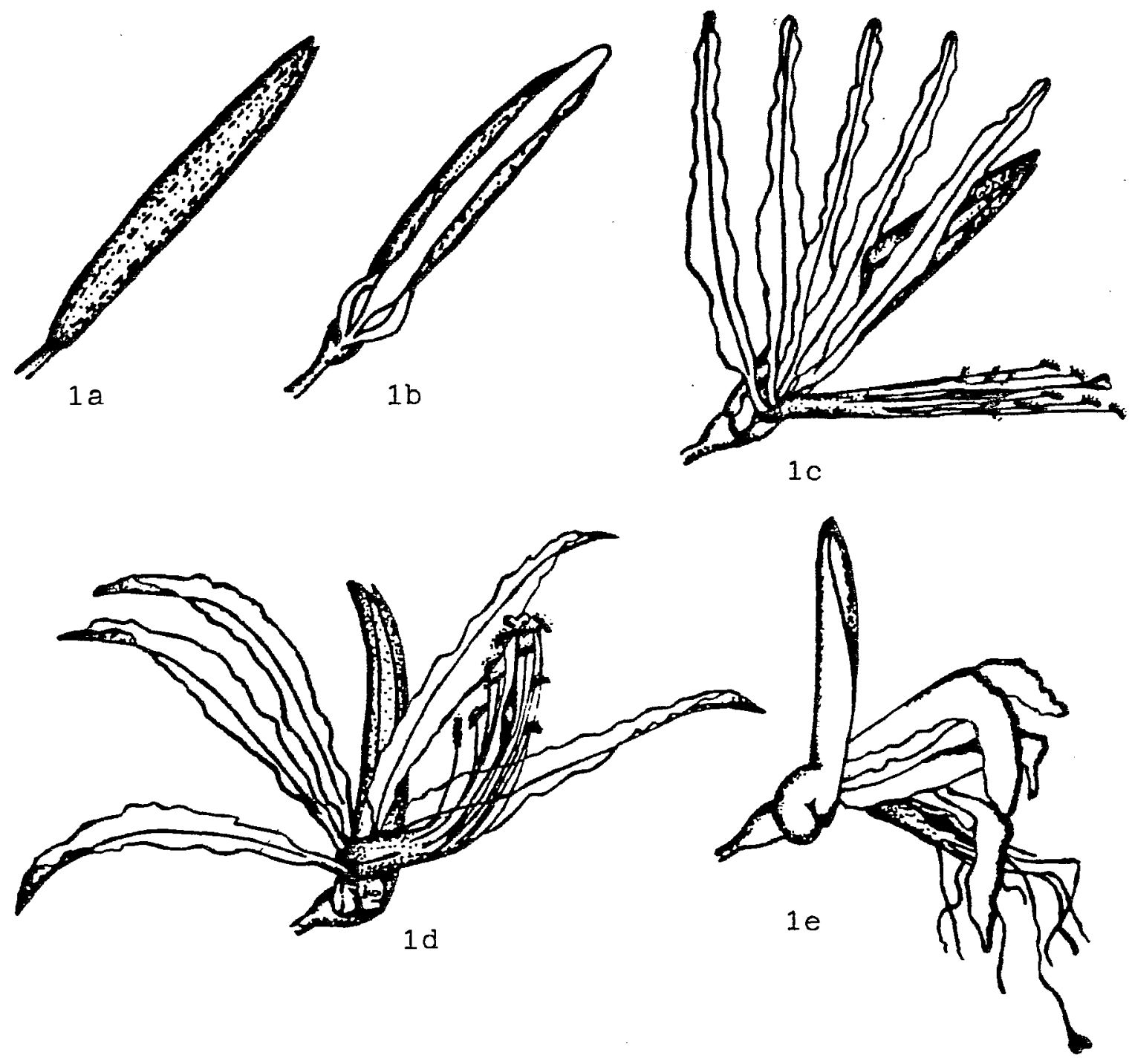

Figura 1- Estádios da antese das flores de Bauhinia forficata. 1a.botão pré-antese; 1b.início da abertura; 1c.exposição completa das es truturas florais; 1 d.antese completa; 1 e. estádio de senescência (12 a 18 hrs. após a abertura). 
Nesta fase, os lobos estigmáticos iniciam a abertura gradativamente e as anteras já se apresentam deiscentes, com pólen disponivel, observando-se inclusive flores com os lobos estigmáticos repletos do próprio pólen. Aproximadamente quarenta minutos após a exposição da flor, todas as suas estruturas curvam-se para cima conforme demonstrado na Figura $1 d$ e, neste momento, os lobos estigmáticos já se encontram completamente abertos.

Cerca de 12 a 15 horas após a antese, especialmente em dias ensolarados e com temperatura elevada as flores apresentam-se em estádio de senescência com as pétạlas parcialmente murchas, os filetes com as extremidades ressecadas e escurecidas, geralmente sem anteras e o gineceu desidratado e pendente (Figura 1e), o que confere com as caracteristicas das plantas quiropterófilas, que em sua maioria apresentam flores que duram apenas uma noite (FAEGRI \& PILJ, 1979).

Os estigmas mostraram-se receptivos durante 12 a 15 horas após a antese, tanto nas análise realizadas com água oxigenada como com o corante Sudan III glicerinado. Após esse período os lobos apresentam-se dessecados e com coloração mais escura tendendo ao marrom e não estão mais receptivos.

o pólen já está disponivel no momento em que 
a flor inicia a antese, e os testes realizados com o corante Carmin acético, utilizando-se pólen coletado de flores ecém abertas, mostraram uma média de $98,89 \pm 0,87 \%$ de grãess de pólen viáveis. As análises realizadas, com pólen coletado 12 horas após a abertura das flores, apreser: aram também alta porcentagem de grãos de pólen viáveis, com média de $85,26 \pm 9,07 \%$.

Estes resultados indicam que as flores de Bauhinis forficata são funcionalmente hermafroditas, apresentiando tanto as estruturas femininas quanto as masculinas ativas.

Entretanto, apesar dos grãos de pólen ainda apresentarem-se viáveis no dia seguinte à abertura das flores, neste período os estames já se encontram desprovidos de anteras ou, quando estas ainda estão presentes, já se encontram praticamente vazias.

Conforme ilustrado nas Figuras $1 c$ e $1 d$, os estames, em número de 10, apresentam as anteras voltadas para cima, com o pólen totalmente exposto. Este tipo de exposição de pólen, característico em espécies do gênero Bauhinia, parece ser bastante eficiente para o transporte por morcegos, sendo ilustrado por GRIBEL et alii (1990). Os autores citados apresentam um registro fotográfico que mostra o morcego glossofagíneo Anoura caudifer visitando uma flor de unha-de-vaca (Bauhinia sp) com a região do 
abdome repleta de grãos de pólen, tocando as anteras que apresentam uma disposição bastante semelhante a verificada em $B$. forficata.

Com relação à presença de néctar, foi verificado que o mesmo localiza-se na base da corola,ou cavidade do hipanto, sendo que o volume médio de néctar acumulado por flor foi de $520 \pm 315 \mathrm{ul}$. Este volume é maior que o volume médio observado em Bauhinia bongardii, de 231,1 ul (BERGALLO, 1990), estando mais próximo do volume encontrado em Bauhinia ungulata, de $621 \mathrm{ul}$, apresentado por RAMIREZ et alii (1984).

A concentração média de açúcares no néctar foi de $16 \pm 0,9 \%$, que está na amplitude de variação conhecida para diversas espécies quiropterófilas, sendo também equivalente às concentrações observadas em outras espécies do gênero Bauhinia. Em Bauhinia ruffa, SAZIMA \& SAZIMA (1978) observaram concentrações de 15\%, enquanto BERGALLO (1990) observou concentração média de $15,6 \%$ em Bauhinia boungardii.

Não foram verificadas regiões coradas nas flores de Bauhinia forficatá, quando utilizou-se o corante vermelho neutro para deteç̧ão de osmóforos, e durante as observações não foi observada a presença de qualquer odor caracteristico proveniente das flores. 


\subsubsection{Análise dos visitantes florais}

Foram observadas 10 espécies de borboletas (Lepidoptera), duas de coleópteros (Coleoptera), uma de vespa (Hymenoptera) e uma de beija-flor (Apodiforme) visitando as flores de Bauhinia forficata, no periodo diurno. Na Tabela 4 estão sumarizados o periodo de visita, o número médio de flores visitadas no periodo e a duração das visitas dos principais grupos de visitantes das flores de $B$. forficata, no período diurno.

Nenhuma das espécies observadas, no período diurno, com exceção do beija-flor, apresentou comportamento de visita que as incluisse como polinizadoras. O beija-flor apresenta algumas 'caracteristicas que sugerem a possibilidade desta espécie atuar como vetor de transferência do pólen. Entretanto, suas visitas foram esporádicas, com apenas duas visitas no período da manhã em um só dia, o que não permitiu observações detalhadas de seu comportamento. Além disso, a baixa frequência de visitas desta espécie sugere que ela não apresenta um papel efetivo na polinização de Bauhinia forficata.

$$
\text { Adicionalmente, conforme demonstrado na }
$$

Figura le, as flores de Bauhinia forficata já se encontram em estádio de senescência no dia seguinte após a noite de abertura, reduzindo, portanto, a possibilidade de qualquer visitante diurno atuar como polinizador da espécie. 
TABÉLA 4. Visitantes florais diurnos de Bauhinia forficata, períodos de visita, números médios de flores visitadas no período (N) e duração média das visitas. Piracicaba, SP, 1994

\begin{tabular}{clll}
\hline & PERfODO & & DURAÇAO \\
- VISITANTES & DE & & DA \\
& VISITA & $\mathrm{N}$ & VISITA \\
\hline
\end{tabular}

Apodiforme

Trochilidae

$\begin{array}{lll}09: 00-12: 00 & 2 & 2 \text { a } 3 \text { seg. } \\ 09: 00-11: 00 & 3 & 3 \text { a } 15 \mathrm{~min} .\end{array}$

Coleoptera

Hymenoptera

Fam. Vespidae

Sinoeca sp. 06:00-12:00 $19 \quad 1$ a 2 min.

Lepidoptera

( 8 espécies)

08:00-14:00 24 2 a 60 seg.

Fam. Hesperiidae

Nascus phocus

Fam. Nymphalidae

Doxocopa kallina 08:00-13:00 $5 \quad 5$ seg.

Além disso, várias características florais de Bauhinia forficata, tais como antese noturna, coloração branca, grande quantidade de pólen disponível e outras, indicam que a espécie apresenta atributos especializados à polinizadores noturnos (FAEGRI \& PIJL, 1979).

Entre os visitantes noturnos de Bauhinia forficata, foram observadas seis espécies distintas de mariposas (Sphingidae e Noctuidae) e uma espécie de morcego (Phyllostomidae) (Tabela 5). 
A espécie de Noctuidae chegava à flor em vôo lateral, pousava na base da corola, segurando-se por um ou dois pares de pernas a uma das pétalas ou aos filetes. Em seguida, introduzia a probóscide na região central da corola, permanecendo cerca de 2 segundos na flor. Após

TABELA 5. Visitantes noturnos em Bauhinia forficata, períodos de visita, números médios de flores visitadas por período (N) e durações das visitas. Piracicaba. SP, 1994

\begin{tabular}{llll}
\hline & PERIODO & & DURAÇสO \\
VISITANTES & DE & \multirow{2}{*}{ DA } & VISITA \\
\hline
\end{tabular}

Lepidoptera

Fam. Sphingidae

21:00-01:00 21

1 a 6 seg.

Pholus satellitia

Pholus fasciatus

Pholus eacus

Triptogon ocypete

Fam. Noctuidae
(1 espécie)
21:00-03:00
8
2 a 3 seg.

Chiroptera
Fam. Phyllostomidae
23:00-03:00
Carollia perspicillata
fração de segundo


isto, deixava a flor, voando por cima das anteras e do estigma, sem tocá-los em nenhum momento da visita. 0 horário de maior frequência de visita ocorria por volta das 23:00 horas, embora tenham sido registradas visitas no período das 21:00 às 03:00 hs.

Os esfingideos observados visitando as flores de Bauhinia forficata pertencem aos gêneros Pholus e Triptogon. As espécies do gênero Pholus ( $P$. satellitia, P. fasciatus, P. eacus) e do gênero Triptogon (T. ocypete) visitavam intensamente as flores, permanecendo cerca de 1 a 6 segundos em cada flor, por tempo variável em cada árvore, algumas vezes visitando várias flores na mesma árvore, outras vezes visitando só uma flor e passando em seguida para uma árvore próxima. Durante as visitas permaneciam em vôo pairado defronte a flor, introduzindo repetidamente a probóscide na porção central da corola, descrevendo movimentos rápidos (fração de segundo) de entrada e saída da flor, durante os quais algumas regiões do corpo poderiam entrar em contato com as estruturas reprodutivas da flor.

Entretanto, nas análises em estereomicroscópio e no microscópio de fluorescência, não foram encontrados grãos de pólen, nem particulas de pó fluorescente, em nenhuma estrutura ou parte do corpo das 
espécies de esfingídeos, inclusive daqueles exemplares coletados durante as visitas. Isto indica que estas espécies provavelmente não estão transportando pólen $e$, portanto, não foram incluídas como prováveis polinizadoras de Bauhinia forficata.

Com relação às visitas de Chiroptera, foi observada apenas uma espécie de Phyllostomidae visitando as flores de Bauhinia forficata. Os dois exemplares capturados com o auxílio da rede de neblina pertenciam a espécie Carollia perspicillata, sendo um macho e uma fêmea.

Esta espécie chegava à flor em vôo frontal, visitando cerca de duas a três florẹs na mesma árvore, pairando em frente à flor com a cabeça voltada para a região central da corola, permanecendo uma fração de segundo em cada flor e abandonando a árvore em seguida. O pico de visita ocorreu das 23:00 às 03:00 horas, como está demonstrado na Tabela 5 .

E possivel que o fato de várias flores apresentarem os filetes desprovidos de anteras, no dia seguinte à abertura das flores, seja consequência de danos mecânicos produzidos pelos morcegos, o que também foi verificado por RAMIREZ et alii (1984) em Bauhinia ungulata. As asas e raspados de pelos das regiões da cabeça, pescoço e abdome dos exemplares de morcegos coletados foram 
analisados em estereomicroscópio e microscópio de fluorescência, revelando a presença de pólen nestas regiões, inclusive grãos de pólen marcados com pó fluorescerite e também partículas de pó fluorescente isoladas, aderidas às asas. Estes resultados sugerem que Carollia perspicillata estava transportando pólen entre individuos de Bauhinia forficata, pois as caracteristicas de comportamento de visita, dimensões do visitante, frequência de visita e presença de pólen, inclusive marcado com pó fluorescente no corpo do animal, qualificam a espécie como polinizadora.

Carollia perspicillata, considerada como uma espécie primariamente frugívora (PEDRO, 1992), também foi observada alimentando-se de néctar de algumas espécies de plantas. Um estudo que mostra este aspecto foi realizado por HEITHAUS et alii (1975), no qual foram avaliados os padrões de alimentação de sete espécies de morcegos em uma floresta tropical, entre elas, Carollia perspicillata. Os autores observaram que a nectarivoria é alta entre as espécies estudadas, inclusive entre aquelas consideradas primariamente frugivoras como, Carollia perspicillata, e ressaltam que a associação do comportamento reprodutivo das plantas com as características de alimentação dos morcegos antófilos promovem fecundação cruzada a longas distâncias, sendo este um importante fator para muitas espécies de 
plantas tropicais que apresentam populações com baixa densidade.

SAZIMA (1976) observou a espécie Carollia perspicillata coletando néctar de flores de Passiflora mucronata e Musa acuminata, mencionando que, durante as visitas, esta espécie de morcego exibe uma extraordinária habilidade de vôo, realizando vôos diretos e curtos ao redor das flores, e coletando o néctar durante um contato muito rápido com a flor. O autor conclui que Carollia perspicillata pode atuar como nectarívoro, sendo que a habilidade de vôo e a ampla ocorrência desta espécie fazem dele um importante agente polinizador.

,HEITHAUS \& FLEMING (1978) estudaram a distância média de vôo de Carollia perspicillata em uma área incluindo tanto floresta como pastagens. Através do acoplamento de transmissores de rádio nos animais, os autores mediram seus movimentos com precisão, registrando distâncias médias de vôo de $1,6 \mathrm{Km}$ entre as áreas de alimentação. Todos os morcegos utilizavam mais de uma "área de alimentação", que é definida pelos autores como locais onde os morcegos gastam ao menos 30 minutos se alimentando. Verificaram ainda que a distância média de vôo foi de 4,7 Km por noite, e que os individuos desta espécie se alimentam solitariamente, não exibem comportamento de territorialidade e atravessam pastagens para se locomover 
entre diferentes áreas de alimentação.

Este tipo de comportamento de Carollia perspicillata pode resultar em importantes consequências sobre a variação genética das populações de Bauhinia forficata, especialmente aquelas que ocorrem em forma de colônias e em áreas abertas, possibilitando cruzamento entre individuos distantes, inclusive entre os indivíduos que se encontram dentro da floresta e os localizados na borda.

4.2. Avaliação do fluxo de pólen

A avaliação do fluxo de pólen, na população estudada de Bauhinia forficata, teve como objetivo principal dimensionar a distância e o número de grãos de pólen transportados pelo polinizador da espécie. Para obter essas in îormações, foram realizadas marcações com pó fluoresce: te e avaliada a transferência de pólen entre plantas. Fimbora as coletas tenham sido realizadas seguindo - protocito apresentado na Tabela 2, nem sempre foi possível roletar o número de flores pré-estabelecido, em função da yariação na quantidade de flores disponíveis nos diferentes dias de coleta (repetições) e nas diferentes classes de jistância.

Os dados sobre o número médio de pólen 
marcado por estigma, com os respectivos desvios padrões e o número de estigmas coletados nas seis classes de distância e sete repetições encontram-se no Apêndice 1 .

Na Tabela 6 encontram-se os valores médios de grãos de pólen marcados, a porcentagem de estigmas marcados em cada uma das repetições e o número de flores coletadas, agrupando-se as classes de distância de cada repetição.

Entre as sete marcações, observa-se que em duas noites (repetições 2 e 6 ) houve uma maior quantidade de pólen transportado, sendo que a repetição 6 apresentou $89,83 \%$ de seus estigmas marcados com pó fluorescente, que é mais que o dobro do verificado nas repetições 1 , 3 e 5 . Na tabela 6 observa-se que o valor de $N$, que corresponde ao número de flores coletadas, é mais alto nas três primeiras repetiçc̃es, quando havia uma maior densidade de floração.

MURAWSKI (1987) verificou que variações na densidacis de floração explicaram quase $50 \%$ das variações observaciàs nas distâncias de dispersão de pólen em Psiguria warscew verifica uno um padrão definido associando a variação na densidade de flores com variações na dispersão de pólen, sendo que as repetições 2 e 6 apresentaram alta transfer ̨ncia de pólen, embora tivessem diferentes números de florç disponiveis na noite da marcação (N). 
TABELA 6. Número médio de flores coletadas (N), número médio de grãos de pólen marcados por estigma (P) e porcentagem de estigmas marcados (E), avaliados em diferentes repetições em uma população natural de Bauhinia forficata. Piracicaba, SP, 1994

\begin{tabular}{cccc}
\hline REP. & $N$ & $P$ & $E(\%)$ \\
\hline 1 & 142 & 1.15 & 40.56 \\
2 & 140 & 3.31 & 72.14 \\
3 & 110 & 0.91 & 43.64 \\
4 & 28 & 2.14 & 53.57 \\
5 & 70 & 2.19 & 44.29 \\
6 & 59 & 6.03 & 89.83 \\
7 & 64 & 2.08 & 65.62 \\
\hline
\end{tabular}

Na Tabela 7 são apresentados dados sobre o número médio de pólen marcado e porcentagem de estigmas marcados nas diferentes classes de distância.

Com relação à transferência de pólen em função da distância da planta marcada, observa-se na Tabela 7 que as maiores porcentagens de estigmas marcados com pó fluorescente estão entre 0 e 20 metros de distância. 
TABELA 7. Número médio de pólen marcado por estigma (P) e porcentagem de estigmas marcados (E), avaliados em seis classes de distância, em uma população natural de Bauhinia forflcata. Piracicaba, SP, 1994

\begin{tabular}{rcc}
\hline DISTANCIA $(\mathrm{m})$ & $\mathrm{P}(\mathrm{s})^{*}$ & $\mathrm{E}$ \\
\hline $0-10$ & $4.00(5,76)$ & 73.53 \\
$10-20$ & $3.22(4,60)$ & 71.87 \\
$20-40$ & $2.68(6,72)$ & 53.04 \\
$40-80$ & $1.23(2,73)$ & 43.31 \\
$80-120$ & $0.86(1,26)$ & 44.90 \\
$120-220$ & $1.21(1,95)$ & 43.48 \\
\hline
\end{tabular}

* Os valores entre parenteses correspondem ao desvio padrão da média

Tanto os dados do número médio de pólen marcado por estigma (P), como os da porcentagens de estigmas marcados (E), mostram a mesma tendência, indicando uma alta transferência de pólen até 20 metros de distância da planta marcada. Os dados referentes a porcentagem de estigmas marcados mostram uma redução de $20 \%$ entre 20 e 40 metros e mantendo-se praticamente constante a partir dos 40 metros, apresentando mais de $40 \%$ dos estigmas marcados na distância máxima de coleta (220 metros). Isto sugere que a transferência de pólen ocorre através de longas distâncias, pois até 220 metros, não se observou diminuições acentuadas 
nas porcentagens de estigmas marcados, nem na quantidade de pólen marcado $(\mathrm{N})$.

Tal resultado difere do observado em outras espécies de plantas (WEBB \& BAWA, 1983; LEVIN \& KERSTER, 1974), em que as curvas de dispersão apresentam padrões leptocúrticos, com diminuições acentuadas à poucos metros da planta marcada. Esta característica da transferência de pólen alcançar longas distâncias está de acordo com o comportamento do polinizador, Carollia perspicillata, que voa vários quilômetros por noite, resultando, portanto, em um fluxo de pólen de longo alcance, na espécie Bauhinia forficata.

\subsection{Avaliação do Sistema Reprodutivo}

a. Interpretação genética dos zimogramas

$$
\mathrm{Na} \text { Figura } 2 \text { são apresentados, }
$$

esquematicamente, os padrões observados nos quatro locos, para os dois sistemas enzimáticos estudados. São também registrados os valores de migração relativa RM e Rf de cada alelo, as lado direito da figura, e todos os genótipos encontrados em cada um dos locos analisados. 
$\mathbf{E} \boldsymbol{\mathbf { E }} \mathbf{1}$

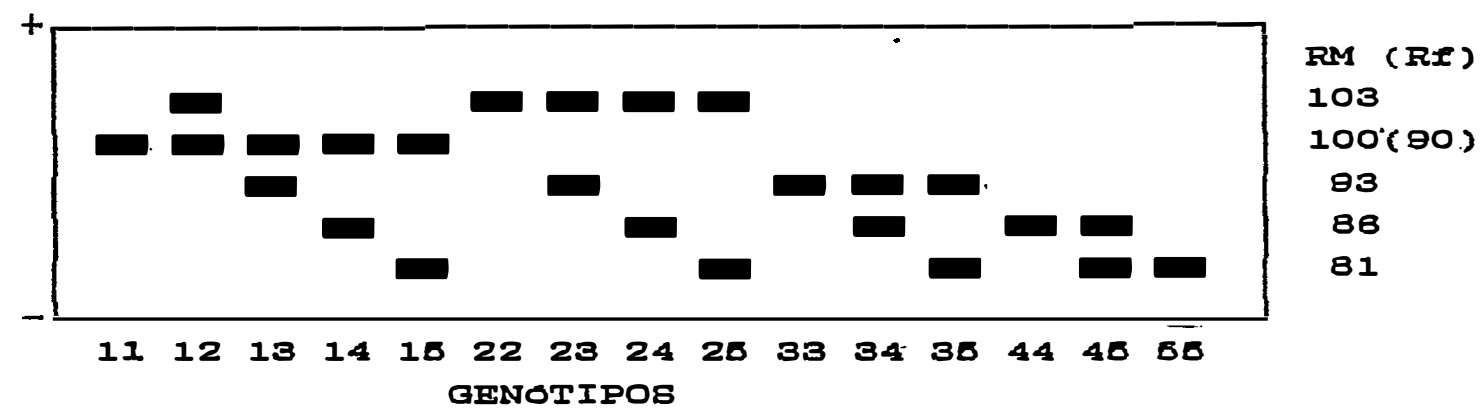

Est-2



$\begin{array}{lllll}11 & 12 & 13 & 23 & 33\end{array}$

GENOTIPOS
EE七ー 3





FIGURA 2. Esquema dos zimogramas apresentando os fenótipos dos locos Est-1, Est-2, Est-3, Idh-1, com seus respectivos valores de RM, Rf e genótipos. 
O sistema isoenzimático ALFA-Esterase (EST) apresentou 3 locos nítidos, que foram utilizados neste estudo. Os heterozigotos presentes nos três locos deste sistema enzimático indicaram que as enzimas têm suas estruturas moleculares compostas por uma subunidade de cadeia polipeptídica, ou seja, são monoméricas.

De acordo com KEPHART (1990), o sistema enzimático EST pode apresentar de dois a dez locos e as enzimas possuem estrutura monomérica ou dimérica. Para Bauhinia forficata, foram utilizados para interpretação somente três locos, mas eram visiveis nos zimogramas aparentemente mais dois locos, sendo um de migração intermediária entre os locos Est-2 e Est-3 e o outro mais rápido que o loco Est-1. Entretanto, eles não foram utilizados pois não apresentaram boa resolução.

Para o loco Est-3, que apresentou migração mais lenta, observou-se três alelos. 0 alelo 2 teve uma migração relativa de 93 em relação ao alelo 1, que recebeu o valor 100 (alelo padrão), e o alelo três apresentou um valor de migração relativa de 86 .

No loco Est-2, de migração intermediária, também foram encontrados três alelos na população estudada, sendo as migrações relativas dos alelos 2 e 3 iguais a 111 e 115 , respectivamente. 
O loco Est-1, o de migração mais rápida, apresentou 5 alelos, sendo seus valores de RM iguais a 103, 93, 86 e 81, para os alelos 2, 3, 4 e 5, respectivamente. Este loco foi o que apresentou melhor resolução e nitidez de bandas para a espécie em estudo.

No sistema enzimático Isocitrato desidrogenase (IDH), houve o aparecimento de somente um loco $(\mathrm{Idh}-1)$ e os heterozigotos apresentam bandas com fenótipo heterodimérico, com valores de RM iguais a 108 para o heterozigoto de genótipo (12), 100 para o heterozigoto (23), 93 para os heterozigotos (13) e (24), 86 para o heterozigoto (14) e 79 para o heterozigoto (34). Os valores de RM foram de $117,86,72$ para os alelos 2,3 , e 4, respectivamente.

b. Frequências alélicas e heterozigosidade nos quatro locos analisados

Todos os locos utilizados foram considerados polimórficos com base no critério de 95\%, ou seja, em nenhum deles o alelo mais comum atingiu valores de frequência superiores a 0,95 . 
Na Tabela 8, estão expostos os dados relativos à frequência de cada um dos 15 alelos encontrados na população estudada, as heterozigosidades esperada e observada em cada um dos locos e as médias para a população.

\section{c. Testes para o Equilíbrio de Hardy-Weinberg}

Para verificar os desvios da panmixia, na população estudada, realizou-se um teste de qui-quadrado.

$\mathrm{Na}$ Tabela 9 encontram-se os valores de $\mathrm{X}^{2}$ para os desvios do equilíbrio de Hardy-Weinberg, obtidos para os quatro locos. Os genótipos foram agrupados em três classes e os valores de probabilidade foram encontrados pelo programa Biosys-1.

Os valores de qui-quadrado obtidos mostram valores : ฐ̃o significativos para três locos, Est-2, Est-3, Idh-1. Fintretanto, o loco Est-1 apresentou desvios significa ivos do equilibrio de Hardy-Weinberg (Tabela 9).

Nota-se na tabela 9 que a classe 2 , onde estão agxupados os individuos heterozigotos compostos pelo alelo mais comum e os outros alelos, mostra um número de heterozigotos observado menor do que o esperado, nos quatro locos analisados. Estes resultados indicam estar havendo uma deficiencia de heterozigotos na população e, apesar de 
TABELA 8. Frequência dos 15 alelos em 4 locos isoenzimáticos, heterozigosidade observada (Ho), heterozigozidade esperada ( $\mathrm{He}$ ) e número de individuos por loco (N) em uma população natural de Bauhinia forficata. Piracicaba, SP, 1994

\begin{tabular}{|c|c|c|c|c|c|}
\hline LOCO & ALELO & FREQ. ALELICAS & Ho & $\mathrm{He}$ & $\mathrm{N}$ \\
\hline \multirow[t]{6}{*}{ Est-1 } & 1 & 0,602 & & & \\
\hline & 2 & 0,048 & & & \\
\hline & 3 & 0,056 & & & \\
\hline & 4 & 0,094 & & & \\
\hline & 5 & 0,200 & & & \\
\hline & & & 0,508 & 0,584 & 250 \\
\hline \multirow[t]{4}{*}{ Est-2 } & 1 & 0,591 & & & \\
\hline & 2 & 0,020 & & & \\
\hline & 3 & 0,389 & & & \\
\hline & & & 0,452 & 0,500 & 252 \\
\hline \multirow[t]{4}{*}{ Est-3 } & 1 & 0,566 & & & \\
\hline & 2 & 0,400 & & & \\
\hline & 3 & 0,034 & & & \\
\hline & & & 0,478 & 0,520 & 249 \\
\hline \multirow[t]{5}{*}{$I d h-1$} & 1 & 0,751 & & & \\
\hline & 2 & 0,025 & & & \\
\hline & 3 & 0,141 & & & \\
\hline & 4 & 0,083 & & & \\
\hline & & & 0,365 & 0,409 & 241 \\
\hline MRDIA & & & 0,451 & 0,503 & \\
\hline
\end{tabular}


TABELA 9. Gui-quadrado ( $\left.\mathrm{X}^{2}\right)$ para os desvios do Bquilíbrio de Hardy-Weinberg, considerando o snúmero observado (No) e esperado (Ne) dos genótipos agrupados em três classes para os quatro locos isoenzimáticos, em uma população natural de $B$. forficata. Piracicaba, SP, 1994

\begin{tabular}{|c|c|c|c|c|c|c|}
\hline LOCO & CI:ASSES 1 & No & $\mathrm{Ne}$ & $x^{2}$ & $\mathrm{GL}^{2}$ & p3 \\
\hline & $\therefore$ & & & & & \\
\hline \multirow[t]{3}{*}{ Est-1 } & 1 & 100 & 90,601 & & & \\
\hline & 2 & 101 & 119,798 & & & \\
\hline & $\because 3$ & 49 & 39,601 & $6,156^{*}$ & 1 & 0,013 \\
\hline \multirow[t]{2}{*}{ Est-2 } & 1 & 93 & 88,099 & & & \\
\hline & 2 & 112 & 121,802 & & & \\
\hline$\therefore$ & 3 & 47 & 42,099 & $1,632^{\mathrm{ng}}$ & 1 & 0,201 \\
\hline \multirow[t]{3}{*}{ Est-3 } & 1 & 85 & 79,843 & & & \\
\hline & 2 & 112 & 122,313 & & & \\
\hline & 3 & 52 & 46,843 & $1,770 \mathrm{~ns}$ & 1 & 0,183 \\
\hline \multirow[t]{3}{*}{$I d h-1$} & 1 & 140 & 135,938 & & & \\
\hline & 2 & 82 & 90,124 & & & \\
\hline & 3 & 19 & 14,938 & $1,958 \mathrm{ng}$ & 1 & 0,162 \\
\hline
\end{tabular}

1 : 1 - número de homozigotos para o alelo mais comum;

2 - número de heterozigotos entre o alelo mais comum e os alelos raros;

3 - número de homozigotos raros e outros heterozigotos;

2 : GL - graus de liberdade

3 : P - probabilidade de ajuste

*: $P<0,05$;

na: não significativo. 
três locos não terem apresentado desvios significativos do equilibrio de Hardy-Weinberg, esta falta de heterozigotos e a presença de um loco apresentando desvios significativos, sugerem a necessidade de realização de outros testes para confirmar a suposição de panmixia completa. Para tanto, foi realizado um teste combinando probabilidades (teste de Fisher), conforme descrito por STEEL \& TORRIE (1980), que está apresentado na Tabela 10 . Os resultados deste teste demonstram um valor de $\mathrm{X}^{2}$ total de 18,94, com 8 graus de liberdade, que é significativo ao nível de $5 \%$, levando a rejeição do equilíbrio de Hardy-Weinberg.

TABELA 10. Combinação de probabilidades de teste de $X^{2}$ (teste de Fisher), para os desvios do equilibrio de Hardy-Weinberg, para os quatro locos identificados por eletroforese, de acordo com STEEL \& TORRIE (1980). Piracicaba, SP, 1994

LOCO Prob. (de $\left.\mathrm{X}^{2}\right) \quad-2 \ln \mathrm{P} \quad$ GL

\begin{tabular}{llll}
\hline Est-1 & 0,013 & 8,69 & 2 \\
Est-2 & 0,201 & 3,21 & 2 \\
Est-3 & 0,183 & 3,40 & 2 \\
Idh-1 & 0,162 & 3,64 & 2 \\
\hline TOTAL & & $18,94^{*}$ & 8 \\
\hline
\end{tabular}

1n: loga (logaritmo neperiano);

* : $\mathrm{p}<0,05$; 
o teste foi aplicado conforme descrito por STEEL \& TORRIE (1980), para combinar probabilidades, sendo a combinação feita através da adição dos valores de $-2 \ln$ P. o uso deste procedimento de combinação requer que as tabelas de critério do teste original sejam razoavelmente completas com respeito aos níveis de $\mathrm{P}$ e que para tal devem ser utilizadas interpolações se necessário. Esta exigência pôde ser satisfeita utilizando-se o resultado do teste de $\mathrm{X}^{2}$ em classes, obtido através do programa Biosys-1, que fornece valores exatos de $\mathrm{P}$ para cada loco, permitindo a utilização deste procedimento, no qual o $\mathrm{X}^{2}$ combinado tem $2 \mathrm{k}$ graus de liberdade, quando " $k$ " probabilidades estão sendo combinadas. Neste caso o número de graus de liberdade foi igual a oito, pois estavam sendo combinadas probabilidades de quatro locos.

Considerando que os testes para o Equilíbrio de Hardy-Weinberg apresentaram desvios significativos, mostrando que a população estudada não é totalmente panmítica, procedeu-se então às análises para obtenção de estimativas da taxa de cruzamento.

4.3.1. Estimativa da taxa de cruzamento aparente $\left(\hat{t}_{a}\right)$

a. Teste para o Equilibrio de Wright (equilibrio de endogamia) 
Para a obtenção da taxa de cruzamento aparente $(\hat{t} a)$, a partir do coeficiente de endogamia $(\hat{f})$, é necessário verificar a existência de Equilíbrio de endogamia na população. Os resultados apresentados na Tabela 11 mostram valores de $\mathrm{X}^{2}$ não signifieativos para os dois locos, o que nos leva a aceitar a hipótese de nulidade e a validade da suposição do equilíbrio de endogamia para a população em estudo. O valor de $\mathrm{X}^{2}$ mais alto foi o da Idh1, que foi igual a 1,857, mas não foi significativo com 2 graus de liberdade, apresentando uma probabilidade de ajuste maior que $30 \%$ de acordo com a tabela. 0 loco Est-1 apresentou valor de $X^{2}$ bastante reduzido, igual a 0,659 e probabilidades de ajuste em torno de $70 \%$.

De acordo com VENCOVSKY (1992), nestas circunstâncias é válido estimar a taxa de fertilização cruzada aparente $(\hat{t} a)$ a partir da estimativa do coeficiente de endogamia $(\hat{f})$.

b. Estimativas de $\hat{\theta}_{1}, \hat{f}$ e $\hat{t a}$

A estimativa do coeficiente de endogamia $(\hat{f})$ foi obtida a partir dos componentes das variâncias, conforme demonstrado na metodologia. As estimativas das variâncias entre famílias, entre indivíduos / famílias, 
TABELA 11. Qui-quadrado para os desvios do Equilibrio de Endogamia (Wright), considerando o número observado (No) e esperado (Ne) dos genótipos agrupados em classes para dois locos isoenzimáticos em uma população natural de Bauhinia forficata. Piracicaba, SP, 1994

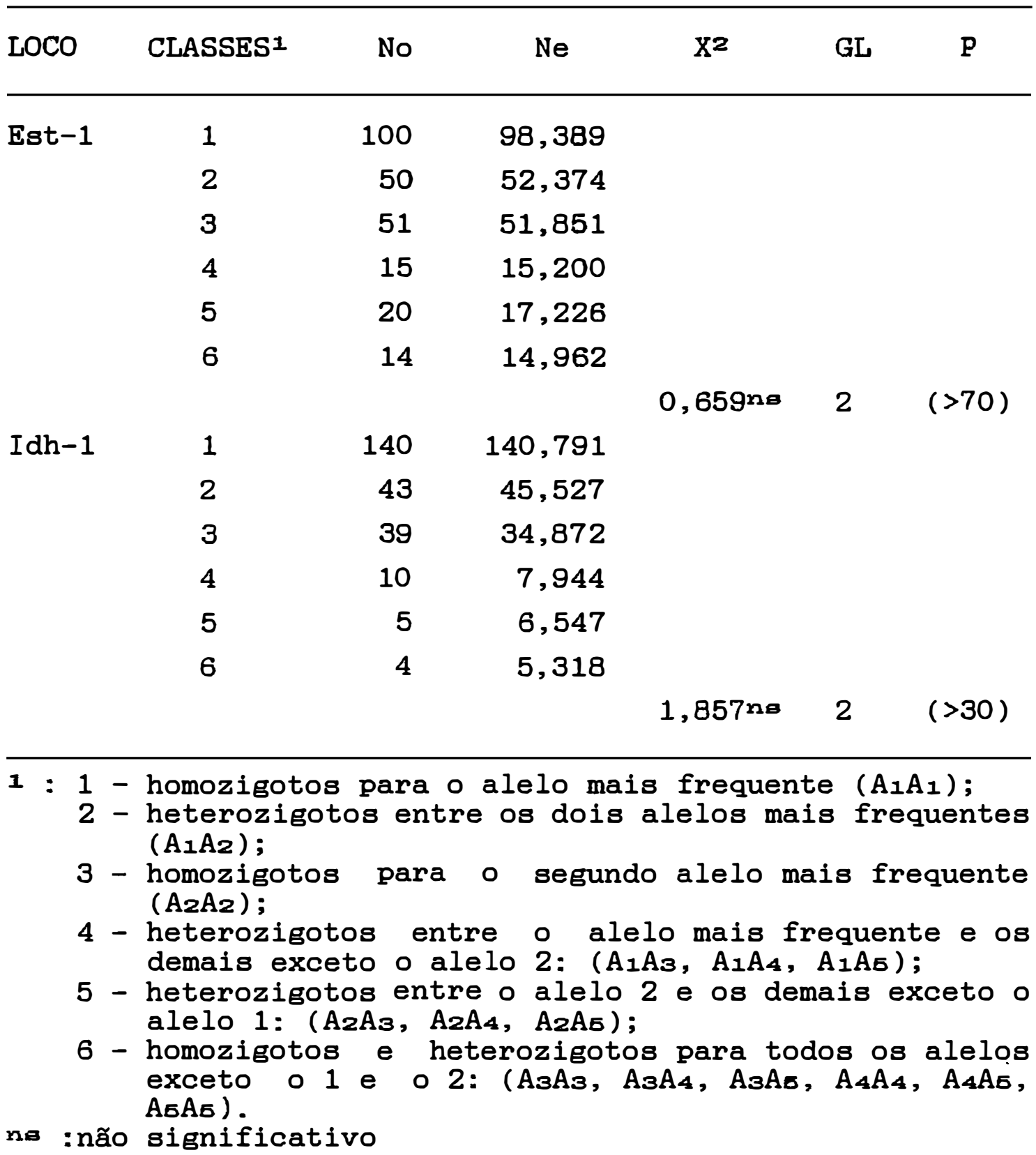


entre genes/indivíduos/famílias e da variância total, para os 15 alelos dos quatro locos, estão apresentados no Apêndice 6. Estas estimativas foram obtidas conforme a metodologia apresentada por WEIR (1990a), a partir dos desdobramentos dos quadrados médios, cujos resultados são apresentados no Apêndice 2 para o loco Est-1, no Apêndice 3 para o loco Est-2, no Apêndice 4 para o loco Est-3 e no Apêndice 5 para $\circ$ loco $\mathrm{Idh}-1$.

As estimativas dos coeficientes de endogamia dentro da população $(\hat{f})$, de parentesco dentro das famílias $\left(\hat{\theta}_{1}\right)$ e da taxa de cruzamento aparente $(\hat{t} a)$, calculados conforme WEIR (1990a) e VENCOVSKY (1992), são apresentados na Tabela 12. As estimativas foram obtidas para cada alelo individualmente, para cada loco (média) e para todos os alelos dos 4 locos através das médias gerais.

- grau de parentesco dentro de famílias $\left(\hat{\theta}_{1}\right)$, obtidos para a população de Bauhinia forficata, foram de 0,1318 na média por loco e de 0,1350 na média por alelo. Este:s valores estão bem próximos de $1 / 8(0,1250)$, que é o grau de parentesco entre indivíduos de famílias de meios irmãos.

Entretanto, o loco Est-3 apresentou um valor discrepante de $\hat{\theta}_{1}(0,0501)$, sendo que os outros três locos mostram valores mais próximos entre si, apresentando um valor medio de $\hat{\theta}_{1}$ igual a 0,1659 , o que indica um grau de 
TABELA 12. Estimativàs dos coeficientes de endogamia dentro da população $(\hat{f})$, de parentesco dentro das famílias $\left(\hat{\theta}_{1}\right)$ e taxa de cruzamento $(\hat{t})$ calculados conforme WEIR (1990a), para 15 alelos em 4 locos isoenzimáticos em uma população natural de Baubinia forficata. Piracicaba, SP, 1994

\begin{tabular}{cccc}
\hline ALELO/LOCUS & $\hat{\theta}_{1}$ & $\hat{\mathbf{f}}$ & $\hat{\mathrm{t}}$ \\
\hline Est1/1 & 0,1655 & 0,1622 & 0,7209 \\
Est1/2 & 0,1339 & 0,1361 & 0,7604 \\
Est1/3 & 0,1290 & 0,0280 & 0,9454 \\
Est1/4 & 0,1299 & 0,1415 & 0,7520 \\
Est1/5 & 0,1391 & 0,1299 & 0,7701 \\
MEDIA & $\mathbf{0 , 1 4 7 7}$ & $\mathbf{0 , 1 3 5 9}$ & $\mathbf{0 , 7 6 0 8}$ \\
Est2/1 & 0,1829 & 0,0949 & 0,8266 \\
Est2/2 & 0,0145 & $-0,0154$ & 1,0312 \\
Est2/3 & 0,1957 & 0,1303 & 0,7695 \\
MEDIA & $\mathbf{0 , 1 8 2 2}$ & $\mathbf{0 , 1 0 7 7}$ & $\mathbf{0 , 8 0 5 6}$ \\
Est3/1 & 0,0611 & 0,0906 & 0,8339 \\
Est3/2 & 0,0427 & 0,0924 & 0,8307 \\
Est3/3 & 0,0260 & $-0,0302$ & $\mathbf{1 , 0 6 2 3}$ \\
MRDIA & $\mathbf{0 , 0 5 0 1}$ & $\mathbf{0 , 0 8 3 4}$ & $\mathbf{0 , 8 4 6 0}$ \\
Idh1/1 & 0,1704 & 0,1350 & 0,7622 \\
Idh1/2 & 0,0234 & $-0,0205$ & 1,0418 \\
Idh1/3 & 0,2219 & 0,1734 & 0,7044 \\
Idh1/4 & 0,1130 & 0,0891 & 0,8364 \\
MRDIA & $\mathbf{0 , 1 6 7 9}$ & $\mathbf{0 , 1 2 8 8}$ & $\mathbf{0 , 7 7 1 8}$ \\
\hline MEDIA GERAL(a) & $\mathbf{0 , 1 3 1 8}$ & $\mathbf{0 , 1 0 9 8}$ & $\mathbf{0 , 8 0 2 1}$ \\
MEDIA GERAL(b) & $\mathbf{0 , 1 3 5 0}$ & $\mathbf{0 , 1 1 4 0}$ & $\mathbf{0 , 7 9 5 3}$ \\
\hline M 1 (b) & & &
\end{tabular}

(a) média por loco;

(b) média por alelo. 
parentesco intermediário entre meios-irmãos e irmãos germanos. Este resultado é semelhante ao obtido por MORI (1993), que estimou valores médios de $\hat{\theta}_{1}$ de 0,1754 para Eucalyptus grandis, que segundo o autor é aproximadamente 1/6, ficando como intermediário entre 1/8, grau de. parentesco entre meios-irmãos e 1/4, grau de parentesco entre irmãos germanos.

Um grau de parentesco ainda maior foi encontrado por MORAES (1992) em Myracrodruon urundeuva, sendo $O$ valor de $\hat{\theta}_{1}$ igual a 0,2957, praticamente 1/3, mostrando um alto grau de parentesco entre indivíduos dentro das famílias.

MORI (1993) obteve valores de coeficientes de endogamia $(\hat{f})$ de 0,1085 em Eucalyptus grandis, indicando a existência de uma parcela de endogamia, o que também foi verificado em Bauhinia forficata, que apresentou valores de $\hat{f}$ de 0,1098 na média por loco e 0,1140 na média por alelo.

Os valores médios da taxa de cruzamento aparente ( $\hat{t a}$ ) obtidos através da análise de variância de WEIR (1990a), foram de 0,8021 na média por loco e 0,7953 na média por alelo. Este valor de ta refere-se à taxa aparente de cruzamento e só é válido quando a população está em equilíbrio de endogamia, o que foi constatado na população estudada. 
para Eucalyptus grandis, sendo a taxa de cruzamento igual a 0,8041 . O autor refere que o estudo foi realizado em um pomar de sementes, instalado a partir de clones não aparentados, e portanto a endogamia presente refere-se a autofecundação.

Em Bauhinia forficata, não é possivel avaliar se a endogamia observada é resultante de autofecundação ou de crúzamentos entre indivíduos aparentados, somente com base nos dados obtidos a partir das análises de variância, pois trata-se de uma população natural. Portanto, foi realizada a estimativa multiloco da taxa de cruzamento $(\hat{t m})$, com 0 intuito de verificar a ocorrência de autofecundação na população estudada e comparar as diferentes estimativas de $\hat{t}$.

\subsubsection{Estimativa multiloco da taxa de cruzamento $(\hat{t} m)$}

A Tabela 13 mostra os resultados das taxas de cruzamento $(\hat{t})$ e seus erros padrões, obtidos pelo método de análise multiloco de RITLAND \& JAIN (1981). São apresentados os resultados relativos à taxa de cruzamento dos locos indivíduais, e o resultado da análise multiloco envolvendo os quatro locos, sendo que os resultados de 
TABELA 13. Estimativas das taxas de cruzamento para locos individuais e multiloco ( $\hat{t} \pm$ erro. padrão-E.P.), estimativas das frequências alélicas do pólen e do óvulo e valores de qui-quadrado para os desvios das frequências genotípicas esperadas no modelo de RITLAND \& JAIN (1981), em quatro locos isoenzimáticos. Piracicaba, SP, 1994

FREQ. GENICA ESTIMADA

\begin{tabular}{|c|c|c|c|c|c|c|}
\hline \multirow[b]{2}{*}{ LOCO } & \multirow[b]{2}{*}{ ALELO } & & & \multirow{2}{*}{$\hat{t} \pm$ E.P. } & \multirow[b]{2}{*}{ GL } & \multirow[b]{2}{*}{$\mathrm{X}^{2}$} \\
\hline & & POLEN & OVULO & & & \\
\hline \multirow[t]{4}{*}{ Est-1 } & 1 & .624 & .577 & & & \\
\hline & 2 & .168 & .269 & & & \\
\hline & 3 & .208 & .154 & & & \\
\hline & & & & $0.887 \pm 0.067$ & 9 & $9.06^{n a}$ \\
\hline \multirow[t]{4}{*}{ Est-2 } & 1 & .625 & .538 & & & \\
\hline & $\therefore 2$ & .326 & .462 & & & \\
\hline & 3 & .049 & .000 & & & \\
\hline & & & & $0.810 \pm 0.076$ & 9 & $7.28^{\text {ne }}$ \\
\hline \multirow[t]{4}{*}{ Est3 } & 1 & .550 & .577 & & & \\
\hline & 2 & .409 & .385 & & & \\
\hline & 3 & .041 & .048 & & & \\
\hline & & & & $1.119 \pm 0.068$ & 9 & $8.33^{\text {na }}$ \\
\hline \multirow[t]{4}{*}{ Idh-1 } & 1 & .683 & .769 & & & \\
\hline & 2 & .151 & .154 & & & \\
\hline & 3 & .166 & .077 & & & \\
\hline & $\cdots$ & & & $0.849 \pm 0.076$ & 9 & $6.45^{\mathrm{ne}}$ \\
\hline MULTII & $\cos$ & & & $0.982 \pm 0.034$ & & \\
\hline
\end{tabular}

ne : não sign! ficativo. 
ambas as análises foram obtidos utilizando-se o programa MLT de RITLAND ( 1990 ).

Este método utiliza estimadores dè máxima verossimilhança para obter as estimativas das taxas de cruzamento, e permite calcular o erro padrão de tm, o que confere uma maior precisão a estimativa da taxa de cruzamento. Além disso, de acordo com RITLAND (1990), podese comparar as taxas de cruzamento dos locos individuais e multiloco, de modo que quando tm-ts apresenta uma diferença positiva, indica a ocorrência de endogamia entre aparentados.

Os resultados apresentados na Tabela 13 mostraram valores não significativos para os quatro locos analisados no teste de qui-quadrado de adequação ao modelo, mostrando que os dados se ajustam às suposições do modelo de cruzamento misto de RITLAND \& JAIN (1981).

Deste modo, a alta taxa de cruzamento multiloco $(\hat{\mathrm{tm}})$ obtida para Bauhinia forficata, de $0,982 \pm$ 0,034, indica que a espécie é preferencialmente alógama, apresentando padrões similares a outras espécies arbóreas tropicais, como as estudadas por O'MALLEY \& BAWA (1987); MURAWSKI et alii (1990); MURAWSKI \& HAMRICK (1991).

MURAWSKI et alii (1990) avaliaram a taxa de cruzamento em Quararibea asterolepis, uma Bombacaceae visitada por esfingideos e morcegos, e verificaram altas 
taxas de cruzamento tanto para a média de locos individuais $(\hat{t} \overline{\mathbf{s}}=0,97)$, como para a estimativa multiloco $(\hat{t} m=i, 008)$, sendo que as estimativas $\hat{t} s$ dos cinco locos analisados variaram entre $0,766 \pm 0,058$ e $1,121 \pm 0,049$, mostrando uma maior variação das estimativas entre locos do que a observada em Bauhinia forficata, que variou de 0,810 \pm 0,076 a $1,119 \pm 0,068$.

A ausência de diferença entre as estimativas de locos individuais e multilocos tem sido discutida por alguns autores, especialmente quando as taxas de cruzamento $(\hat{t} \mathrm{~m})$ obtidas são baixas, indicando a ocorrência de endogamia.

MURAWSKI \& HAMRICK (1992b) observaram uma taxa de cruzamento ( $\hat{t} s$ e $\hat{t}_{m}$ ) de cerca de $69 \%$ em Ceiba pentandra. Os autores concluem que a endogamia aparente é resultante de autofecundação e não de cruzamentos entre aparentados, devido à ausência de diferença entre as estimativas obtidas a partir da média dos locos individuais $(\hat{t} \bar{s})$ e a estimativa multiloco $(\hat{t} m)$.

Entretando, RITLAND \& EL-KASSABY (1985) verificaram taxas de endogamia de $7 \%$ em uma espécie de conifera, sendo que tanto a média dos locos individuais, como a estimativa multiloco, apresentaram praticamente os mesmos resultados. Os autores realizaram uma análise de regressão para estimar a propoŗ̣a de endogamia causada por 
cruzamentos entre aparentados e a proporção causada por autofecundação e verificaram que a endogamia presente foi devida a cruzamentos entre aparentados.

Em Bauhinia forficata observou-se que a estimativa multiloco da taxa de cruzamento ( $\hat{t m}$ ) foi de $0,982 \pm 0,034$, enquanto que a média dos locos individuais foi de 0,916, mostrando portanto uma diferença positiva entre as duas, sendo $\hat{t} \mathrm{~m}-\hat{\mathrm{t}} \overline{\mathrm{s}}=0,066$ que de acordo com RITLAND (1990), sugere a existência de endogamia devida a cruzamentos entre indivíduos aparentados. Este resultado está de acordo com o obtido através da análise de variância, que mostrou uma taxa de cruzamento de 0,8021 e um coeficiente de endogamia de 0,1098, indicando que a endogamia observada é, provavelmente, resultante de cruzamentos entre individuos aparentados.

4.5. Implicações das caracteristicas da biologia reprodutiva de Bauhinia forficata

A existência de cruzamentos entre aparentados em Bauhinia forficata pode ser explicada pelo fato dos individuos analisados pertencerem à uma população colonizadora, que pode ter sido fundada por um número 
reduzido de individuos, através de sementes oriundas de uma ou poucas árvores localizadas dentro da floresta e próximas à margem do fragmento.

Adicionalmente, observa-se na Tabela 7 que grande quantidade do pólen transportado, e cerca de $70 \%$ dos estigmas marcados com pó fluorescente, estão distribuidos entre 0 e 20 metros da planta marcada, e considerando que a dispersão de sementes ocorre por autocoria (a curtas distâncias), fica reforçada a possibilidade de ocorrer cruzamento entre individuos aparentados. Assim, existem fatores nesta espécie que podem levar à ocorrência de níveis elevados de endogamia no processo de colonização.

Entretanto, o comportamento do polinizador de Bauhinia forficata pode levar a cruzamentos entre individuos distantes (até $4,7 \mathrm{Km}$, conforme HEITHAUS \& FLEMING, 1978), inclusive entre os individuos localizados na borda do fragmento (população estudada) e os individuos de dentro da floresta, resultando em altas taxas de cruzamento. Isto também é reforçado pelas observações de distâncias de fluxo de pólen, que indicam altas porcentagens de transferência de pólen à distâncias de 220 metros, verificando-se mais de $40 \%$ dos estigmas marcados na distância máxima de avaliação (Tabela 7).

Estas caracteristicas do sistema reprodutivo de Bauhinia forficata, tais como polinizador de vôo longo, 
fluxo de pólen extenso e altas taxas de fecundação cruzada, indicam que a espécie é predominantemente alógama e sugerem, ainda, que pode haver uma rápida ampliação da variabilidade genética em populações recém implantadas, o que pode favorecer a ocupação de novos ambientes. Aliado a isto, a espécie também apresenta crescimento rápido, reprodução precoce (BELTRATI \& PAOLI, 1989) e propagação vegetativa (RODRIGUES et alli, 1990), características que também favorecem a colonização de novas áreas. 


\section{CONCLUSOEES}

a. A espécie Bauhinia forficata apresenta flores funcionalmente hermafroditas.

b. Carollia perspicillata apresenta comportamento de visita e distância de vôo que garantem a sua eficiência como polinizador, promovendo fecundação cruzada e fluxo de pólen à longa distância em Bauhinia forficata.

c. A transferência de pólen à longas distâncias, além de 200 metros da planta marcada, mostra uma extensa movimentação de alelos, através dos grãos de pólen, em Bauhinia forficata.

d. A estimativa multiloco da taxa de cruzamento de Bauhinia forficata é alta $(0,982 \pm 0,034)$, sendo coerente com o comportamento do polinizador e a distância de fluxo de pólen estimada na população.

e. Parte da endogamia observada na população estudada é resultante de parentesco entre as plantas genitoras.

f. Os resultados obtidos sobre a polinização, a distância de fluxo de pólen e o sistema reprodutivo de Bauhinia forficata mostram coerência com o comportamento de colonizadora que a espécie apresenta. 


\section{REFERENCIAS BIBILIOGRÁFICAS}

AIDE, T.M. The influence of wind and animal pollination on variation in outcrossing rates. Evolution, 40(2): 434$435,1986$.

ALFENAS, A.C.; PETERS, I.; BRUNE, W.; PASSADOR, G.C. Eletroforese de proteinas $e$ isoenzimas de fungos $e$ essências florestais. UFV, Viçosa-M.G., 1991. 242p.

BAKER, H.G. Chemical aspects of the pollination biology of woody plants in the tropics. In: TOMLINSON, P.B. \& ZIMMERMAN, M.H. eds. Tropical trees as living systems. Cambridge, Cambridge University Press, 1978, 675p.

BAWA, K.S. Breeding systems of tree species of a lowland tropical community. Evolution, 28: 85-92, 1974.

BAWA, K.S. Plant-pollinator interactions in tropical rain forests. Annual Review of Ecology and Systematics, 21: $399-422$, 1990 .

BELTRATI, C.M. \& PAOLI, A.A.S. Morfologia, anatomia e desenvolvimento de sementes e plântulas de Bauminia forficata Link. (Leguminosae-Caesalpinoideae). Revista Brasileira de Biologia, Rio de Janeiro, 49(2): 583-590, maio, 1989 . 
BERGALLO, H.G. Biologia floral e polinização de Bauhinia bongardii Steud na Serra dos Carajás, Pará. Revista Brasileira de Biologia, Rio de Janeiro, 50(2): 401-405, maio, 1990.

BENTHAM, G. Leguminosae II et III (Swartiziae, Caesalpinieae, Mimoseae). In: MARTIUS, C.F.P. Flora brasiliensis, Monaco, C. Wolf and Fil, 1870, vol. 15, part 2 .

BROWN, A.H.D.; BURDON, J.J.; JAROSZ, A.M. Isozyme analysis of plant mating systems. In: SOLTIS, D.E. \& SOLTIS, P.S., ed. Isozymes in plant biology. Portland, Oregon, Dioscorides Press, 1989. cap 3, p.73-86.

BROYLES, S.B. \& WYATT, R. Effective pollen dispersal in a natural population of Asclepias exaltata: the influence of pollinator behavior, genetic similarity, and mating success. The American Naturalist, Chicago, 138(5): 1239-1249, november, 1991.

BUZATO, S. \& FRANCO, A.L.M. Tetrastylis ovalis: a second case of bat-pollinated passionflower (Passifloraceae). Plant Systematics and Evolution, 181(3-4): 261-267, 1992 .

CAMPBELL, D.R. \& WASER, N.M. Variation in pollen flow within and among population of Ipomopsis aggregata. Evolution, 43(7): 1444-1455, 1989.

CARVALHO, C.T. de. Das visitas de morcegos às flores (Mammalia, Chiroptera). Anais da Academia Brasileira de Ciências, 32(3/4): 359-377, dezembro, 1960. 
CHELIAK, W.N. \& PITTEL, J.A. Techniques for Stapch gel Electrophoresis of Enzymes from Forest Tree Species. Pataya National Forestry Institute, Canadian Forestry Service Information Report PI-X-42, 1984. 49p.

CORREA, M.P. Dicionário das plantas üteis do Brasil e das exóticas cultivadas. Rio de Janeiro, Instituto Brasileiro de Desenvolvimento Florestal, Ministério da Agricultura, 1984. vol.5, 687p.

COSTA, L.G.S. Estrutura e dinâmica de trecho de mata mesófila semidecídua, na Estação Ecológica de Ibicatu, Piracicaba, SP. São Paulo, 1992. 182p. (Mestrado Instituto de Biociências - USP).

CRESTANA, C.S.M.; DIAS, I.S.; MARIANO, G. Ecologia de polinização de Hymenaea stilbocarpa Hayne, o jatobá. Silvicultura, São Paulo, 17/19: 31-37, 1983/85

CRONQUIST, A. An integrated system of classification of flowering plants. New York, Columbia University Press, 1981. 1262p.

DEVLIN, B. \& ELLSTRAND, N.C. The development and application of a refined method for estimating gene flow from angiosperm patternity analysis. Evolution, $44(2): 248-259,1990$.

De VRIES, P.S. The butteflies of Costa Rica and their natural history. Princeton, New Jersey, Princeton University Press, 1987. 327p.

EGUIARTE, L.E.; BURQUEZ, A.; RODRIGUEZ, J. ; MARTINEZ-RAMOS, M.; SARUKHAN, J.; PIÑERO, D. Direct and indirect 
estimates of neighborhood and effective population size in a tropical palm, Astrocaryum mexicanum. Evolution, $47(1): 75-87,1993$.

ELLSTRAND, N.C. \& MARSHALL, D.L. Interpopulation gene flow by pollen in wild radish, Raphanus sativus. The American Naturalist, Chicago, 126: 606-616, november, 1985 .

EHRLICH, P.R. \& RAVEN,'P.H. Differentiation of populations. Gene flow seems to be less important in speciation than the neo-Darwinians thought. Science, Whashington, 165: 1228-1232, September, 1969.

FAEGRI, K. \& PIJL, L. van der. The principles of pollination ecology. London, Sin. Ass. 1979, 224p.

FENSTER, C.B. Gene flow in Chamaecrista fasciculata (Leguminosae). I. Gene dispersal. Evolution, 45(2): 398-409, 1991a.

FENSTER, C.B. Gene flow in Chamaecrista fasciculata (Leguminosae). II. Gene establishment. Evolution, $45(2): 410-422,1991 \mathrm{~b}$.

FERRAZ, E.M.; GANDARA, F.B.; CUNHA, N.L.; REIS, M.S.: KAGEYAMA, P.Y. Eletroforese de isoenzimas para especies arbóreas - Manual de laboratório (versão 1994). Piracicaba, ESALQ, Departamento de Ciências Florestais, Laboratório de Biologia Reprodutiva e Genética de Espécies Arbóreas, 1994. 23p.

FISCHER, E.A.; JIMENEZ, F.A.; SAZIMA, M. Pollination by bats in two species of Bombacaceae at the Ecological 
Station of Juréia, São Paulo. Revista Brasileira de Botânica, 15(1): 67-72, 1992.

FRANKIE, G.W. \& BAKER, H.G. The importance of pollinator behavior in the reproductive biology of tropical trees. Anales Instituto di Biologia, Universidad Nacional Autónoma de México, Serie Botánica, México, 45(1):1-10, 1974 .

FUTUYMA, D.J. Biologia Evolutiva. 2.ed. Ribeirão Preto, Sociedade Brasileira de Genética/CNPq, 1992. 646p.

GODT, M.J.W. \& HAMRICK, J.L. Patterns and levels of pollenmediated gene flow in Lathyrus latifolius. Evolution, 47(1): $98-110,1993$.

GRANT, V. Gene flow and the homogeneity of species populations. Biologisches Zentralblatt, 99: 157-169, 1980.

GRIBEL, R.; SAZIMA, I.; SAZIMA, M. Flores pedem morcegos. Ciência Hoje, Rio de Janeiro, 11(61): 22-28, janeirofevereiro, 1990.

HAMRICK, J.L. Gene flow and distribution of genetic variation in plant populations. In: URBANSKA, $\mathrm{K}$. ed. Differentiation patterns in higher plants. New York, Academic Press, 1987. cap.3, p.53-67.

HANDEL, S.N. Dynamics of gene flow in an experimental population of Cucumis melo (Cucurbitaceae). American Journal of Botany, 69(10): 1538-1546, 1982.

HANDEL, S.N. \& MISHKIN, J.L.V. Temporal shifts in gene flow 
and seed set: evidence from an experimental population of Cucumis sativus. Evolution, 38(6): 1350-1357, 1984.

HEITHAUS, E.R. \& FLEMING, T.H. Foraging movements of a frugivorous bat, Carollia perspicillata (Phyllostomatidae). Ecological Monographs, 48: 127-143, 1978.

HEITHAUS, E.R.; FLEMING, T.H.; OPLER, P.A. Foraging patterns and resource utilization in seven species of bats in a sazonal tropical forest. Ecology, 56: 841854,1975 .

HEITHAUS, E.R.; OPLER, P.A.; BAkER, H.G. Bat activity and pollination of Bauhinia pauletia: plant-pollinator coevolution. Ecology, 55: 412-419, 1974.

HOKCHE, O. \& RAMIREZ, N. Pollination ecology of seven species of Bauhinia L. (Leguminosae: Caesalpcinoideae). Annals of Missouri Botanical garden, 77: 559-572, 1990.

JANZEN, D.H.. Euglossine bees as long-distance pollinators of tropical plants. Science, Washington, 171: 203-205, 1971.

JOHANSEN, D.A. Plant microtechnique. New York, McGraw-Hill book company, 1940 .

KAGEYAMA, P.Y. Conservação "in situ" de recursos genéticos de plantas. IPEF, Piracicaba, 35: 7-40, abril, 1987.

KAGEYAMA, P.Y. \& CASTRO, C.F.A. Sucessão secundária, estrutura genética e plantações de espécies arbóreas 
nativas. In: SIMPOSIO INTERNACIONAL: ALTERNATIVAS PARA O DESMATAMENTO NA AMAZÔNIA. Belém, 1988. Trabalho apresentado.

KAGEYAMA, P.Y.; CASTRO, C.F.A.; CARPANEZZI, A.A. Implantação de Matas Ciliares: estratégias para auxiliar a sucessão secundária. In: SIMPOSIO SOBRE MATA CILIAR, São paulo, 1989. Anais. Campinas, Fundação Cargill, 1989. p.130-143.

KAGEYAMA, P.Y.; REIS, A.; CARPANEZZI, A.A. Potencialidades e restrições da regeneração artificial na recuperação de áreas degradadas. In: SIMPOSIO NACIONAL DE RECUPERAÇÃO DE AREAS DEGRADADAS, Curitiba, 1992. Anais. Curitiba, 1992. p.1-7.

KEPHART, S.R. Starch gel electrophoresis of plant isozymes: a comparative analyses of tecniques. American Journal of Botany. 77(5): 693-712, 1990.

KLEIN, R. M. Ecologia da flora e vegetação do Vale do Itajai. Sellowia, Itajai, 31: 10-164, 1979.

KOTCHETKOFF-HENRIQUEZ, O. \& JOLY, C.A. Estudo florístico da Mata ciliar do Rio Passa Cinco, Serra do Itaquiri, Itirapina, SP. In: XXXIX CONGRESSO NACIONAL DE BOTÂNICA, Belém, Pará, 1988. Anais, 1988, p.465.

LEVIN, D.A. \& KERSTER, H.W. Gene flow in seed plants. In: DOBZHANSKY, T.: HECHT, M.K.: STEENE, W.D., ed. Evolutionary Biology, New York, Plenum Press, 1974 , p. 139-220.

LINHART, Y.B. \& FEISINGER, P. Plant-hummingbird 
interactions: effects of island size and degree of specialization on pollination. Journal of Ecology, 68: $745-760,1980$.

MARTINS, P.S. Aspectos da biologia de populaçòes de leguminosas herbáceas brasileiras. In: I COLOQUIO SOBRE CITOGENETICA E EVOLUÇãO DE PLANTAS, 1., Piracicaba, 1984. Anais. Piracicaba, 1984, janeiro, p.173-184.

MARTINS, P.S. Estrutura populacional, fluxo gênico e conservação "in situ". IPEF, Piracicaba, 35: 71-78, abril, 1987.

MATTHES, L.A.F. Composição florística, estrutura e fenologia de uma floresta residual de planalto Paulista: Bosque dos Jequitibás (Campinas, SP). Campinas, 1980. p. (Mestrado - Instituto de Biologia, Universidade Estadual de Campinas - UNICAMP).

MORAES, M.L.T. Variabilidade genética por izoenzimas e caracteres quantitativos em duas populações naturais de aroeira Myracrodruon urundeuva F.F. \& M.F. Allemão Anacardiaceae (Syn: Astronium urundeuva (Fr. Allemão) Engler. Piracicaba, 1992. 139p. (Doutorado - Escola Superior de Agricultura "Luiz de Queiroz"-USP).

MORELLATO, L.P.C. História natural da Serra do Japi. Ecologia e preservaça de uma área florestal no Sudeste do Brasil. Campinas, Ed. da UNICAMP/FAPESP, 1992. 321p.

MORI, E.S. Variabilidade genética isoenzimática em uma população de Eucalyptus grandis Hill. ex Maiden submetida a diferentes intensidades de selecão. Piracicaba, 1993. 119p. (Doutorado-Escola Superior de 
Agricultura "Luiz de Queiroz"/ USP).

MURAWSKI, D.A. Floral resource variation, pollinator response, and potential pollen flow in Psiguria warscewiczii. Ecology, 68(5): 1272-1282, 1987.

MURAWSKI, D.A. \& HAMRICK, J.L. The effect of the density of flowering individuals on the mating systems of nine tropical tree species. Heredity. 67: 167-174, 1991.

MURAWSKI, D.A. \& HAMRICK, J.L. The mating system of Cavanillesia plantanifolia under extremes of floweringtree density: a test of predictions. Biotropica, 24(1): 99-101, 1992a.

MURAWSKI, D.A. \& HAMRICK, J.L. Mating system and phenology of Ceiba pentandra (Bombacaceae) in Central Panama. Journal of Heredity, 83: 401-404, 1992b.

MURAWSKI, D.A.; HAMRICK, J.L.; HUBBELL, S.P.; FOSTER, R.B. Mating systems of two Bombacaceous trees of a neotropical moist forest. Oecologia, Berlin, 82: 501506,1990 .

O'MALLEY, D.M. \& BAWA, K.S. Mating system of a tropical rain forest tree species. American Journal of Botany, $74(8)$ : 1143-1149, 1987 .

O'MALLEY, D.M.; BUCKLEY, D.P.; PRANCE, G.T.; BAWA, K.S. Genetics of Brazil nut (Bertholletia excelsa Humb. \& Bonpl.: Lecythidaceae). 2. Mating system. Theoretical and Applied Genetics, 76: 929-932, 1988.

PEDRO, W.A. Estrutura de uma taxocenose de morcegos da 
Reserva do Panga (Uberlândia, $M G$ ), com ênfase nas relações tróficas em Phyllostomidae (Mammalia: Chiroptera). Campinas, 1992. 110p. (Mestrado Instituto de Biologia, Universidade estadual de Campinas/UNICAMP) .

PRANCE, G.T. The pollination. of Amazonian plants. In: PRANCE, G.T. \& LOVEJOY, T.E., eds. Key environments: Amazônia. London, Pergamon Press, 1985. cap.9, p.166191.

RADFORD, A.E.; DICKSON, W.C.; MASSEY, J.R.; BELL, C.R. Vascular plant systematics. New York, Harper and Row Publ. 1974.

RAMIREZ, N.; SOBREVILA, C.; ENRECH, N.X.; RUIZ-ZAPATA, T. Floral biology and breeding system of Bauhinia Benthamiana Taub. (Leguminosae), a bat-pollinated tree in Venezuelan "llanos". American Journal of Botany, $71(2)$ : 273-280, 1984 .

REZENDE, M.H. Anatomia foliar comparada de duas espécies de Bauhinia L. (Leguminosae - Caesalpinoideae). Botucatu, 1987. 72p. (Mestrado - Instituto Básico de Biologia Médica e Agrícola - UNESP).

RITLAND, K. A series of FORTRAN computer programs for estimating plant mating systems. The Journal of Heredity, 81(3): 235-237, 1990.

RITLAND, K. \& EL-KASSABAY, Y.A. The nature of inbreeding in a seed orhard of Douglas-fir as show by an efficient multilocus model. Theoretical and Applied Genetics, 71: $374-384,1985$. 
RITLAND, K. \& JAIN, S. A model for the estimation of outcrossing rate and gene frequencies using $n$ independent loci. Heredity, 47(1): 35-52, 1981.

RODRIGUES, R.R.; MATTHES, L.A.F.; TORRES, B.B. Espécies arbóreas - Distribuição agregada ou reprodução vegetativa? In: $\mathrm{V}$ CONGRESSO LATINOAMERICANO DE BOTÂNICA, Havana, 1990. Anales. Havana, 1990. p.54.

SAZIMA, I. Observations on the feeding habits of phyllostomatid bats (Carollia, Anoura and Vampyrops) in Southeastern Brazil. Journal of Mammalogy, 57(2): 381382 , may, 1976.

SAZIMA, M. \& SAZIMA, I. Quiropterofia em Lafoensia pacari St. Hil. (Lythraceae), na Serra do Cipó, Minas Gerais. Ciência e Cultura, 27(4): 405-416, 1975.

SAZIMA, M. \& SAZIMA, I. Bat pollination of the Passion flower, Passiflora mucronata in Southeastern Brazil. Biotropica, 10(2): 100-109, 1978 .

SCHACHT, W.H.; LONG, J.N.; GOBENA, A. Aboveground biomass accumulation in coppicing woodland, northeast Brazil. Forest Ecology and Management, 55: 201-208, 1992.

SLATKIN, M. Rare alleles as indicators of gene flow. Evolution, 39(1): 53-65, 1985.

SOLTIS, D.E.; HAUFLER, C.H.; DARROW, D.C.; GASTONY, G.L. Starch gel electrophoresis of ferns: a compilation of grinding buffers, gel and electrode buffers, and staining schedules. American Fren Journal, 73(1): 9-26, 
1983.

STEEL, R.G.D. \& TORRIE, J.H. Principles and procedures of statistics, 2a ed.. New York, McGraw Hill, 1980, p. 475.

STUBER, C.W.; WENDEL. J.F.; GOODMAN, M.M.; SMITH, J.S.C. Techniques and scoring procedures for starch gel electrophoresis of enzymes from maize (Zea mays L.). North Carolina, North Carolina University, 1988, 87p. Technical Bulletin 286.

SWOFFORD, D.L. \& SELANDER, R.B. A computer program for the analysis of allelic variation in population genetics and biochemical systematics. Illinois, Release 1.7. Swofford, D.L. 1989. Natural History Survey. 43p.

THOMSON. J.D. \& THOMSON. B.A. Dispersal of Erythronium grandiflorum pollen by bumblebees: implications for gene flow and reproductive success. Evolution, 43(3): $657-661,1989$.

VAZ, A.M.S.F. Considerações sobre a taxonomia do gênero Bauhinia L. Sect. Tylotaea Vogel (LeguminosaeCaesalpinoideae) do Brasil. Rodriguesia, XXXI(51) 127$234,1979$.

VENCOVSKY, R. Análise de variância de frequências alélicas. In: CONGRESSO LATINO AMERICANO DE GENETICA, 10, Rio de Janeiro, 1992. Proceedings, Revista Brasileira de Genética. Suplemento 1, Ribeirão Preto, 15(1): 53-60, 1992 .

VOGEL, S. Ecophysiology of zoophyllic pollination. In: LANGE, O.L.; NOBEL, P.S.; OSMOND, C.B.; ZIEGLER, H. 
eds. Physiology plant ecology III. Berlin, SpringerVerlag, 1963. p.560-624.

WASER, N.M. \& PRICE, M.V. A comparison of pollen and fluorescent dye carry-over by natural pollinators of Ipomopsis aggregata (Polemoniaceae). Ecology, 63(4): 1168-1172, august, 1982.

WEBB, C.J. \& BAWA, K.S. Pollen dispersal by hummingbirds and butterflies: a compative study of two lowland tropical plants. Evolution, 37(6): 1258-1270, 1983.

WEIR, B.S. Genetic data analyses. Methods for discrete population genetic data. North Cartolina State University, Sinauer Associates Inc. Publishers, Suderland, Massachusetts, 1990a. 377p.

WEIR, B.S. Intraspecific differentiation. In: HILLIS, D.M. \& MORITZ, C. Molecular Systematics. Sunderland, Massachusetts, Sinauer Associates, Inc. Pub. $1990 \mathrm{~b}$. cap. 10, p. 373-405.

WRIGHT, S. Coefficients of inbreeding and relationship. American naturalist, 56: 330-338, 1922.

ZEISLER, M. Uber die Abgrenzung der eigentlichen Narbenflche mit Hilfe Reaktionen. Beih. Bot. Zbl., 58: 308-318, 1938. 


\section{APENDICES}

APENDICE 1. Número médio de pólen marcado por estigma $(X)$ e número de estigmas analisados (N), em seis classes de distância e sete repetições em uma população natural de Bauhinia forficata. Piracicaba, SP, 1994

\begin{tabular}{|c|c|c|c|c|c|c|c|c|}
\hline \multirow{2}{*}{\multicolumn{2}{|c|}{$\begin{array}{l}\text { CLASSES } \\
\text { DE } \\
\text { DISTANCIA }\end{array}$}} & \multicolumn{7}{|c|}{ REPET I ÇסES } \\
\hline & & (m) 1 & 2 & 3 & 4 & 5 & 6 & 7 \\
\hline \multirow[t]{3}{*}{$0-10$} & $\mathrm{~N}$ & 20 & 20 & 16 & 5 & 15 & 9 & 17 \\
\hline & $X$ & 2.75 & 4.30 & 2.37 & 5.20 & 3.93 & 11.78 & 2.23 \\
\hline & & $(2.31)$ & $(3.42)$ & $(4.15)$ & $(6.42)$ & $(7.87)$ & $(10.92)$ & $(2.54$ \\
\hline \multirow[t]{3}{*}{$10-20$} & $\mathrm{~N}$ & 20 & 20 & 22 & 12 & 18 & 20 & 16 \\
\hline & $X$ & 2.85 & 7.35 & 0.23 & 1.25 & 1.50 & $6.30^{\circ}$ & 2.19 \\
\hline & & $(2.32)$ & $(5.46)$ & $(0.43)$ & $(1.42)$ & $(1.76)$ & $(7.04)$ & $(3.12$ \\
\hline \multirow[t]{3}{*}{$20-40$} & $\mathrm{~N}$ & 30 & 20 & 20 & 4 & 15 & 16 & 10 \\
\hline & $X$ & 0.47 & 5.15 & 0.55 & 3.00 & 3.60 & 6.44 & 1.10 \\
\hline & & $(0.78)$ & $(4.08)$ & $(0.69)$ & $(3.83)$ & $(11.09)$ & $(12.64)$ & $(1.29$ \\
\hline \multirow[t]{3}{*}{$40-80$} & $\mathrm{~N}$ & 22 & 30 & 20 & 5 & 20 & 11 & 20 \\
\hline & $X$ & 0.59 & 1.30 & 1.20 & 1.40 & 0.65 & 1.18 & 2.45 \\
\hline & & $(1.44)$ & $(1.39)$ & $(1.91)$ & $(3.13)$ & $(2.03)$ & $(0.98)$ & $(5.15)$ \\
\hline \multirow{3}{*}{\multicolumn{2}{|c|}{$80-120$}} & - & 20 & 22 & - & 2 & 2 & 1 \\
\hline & & - & 1.35 & 0.59 & - & 0.0 & 1.0 & 0.0 \\
\hline & & - & $(1.42)$ & $(1.14)$ & - & $(0.0)$ & $(0.0)$ & $(0.0)$ \\
\hline \multirow[t]{3}{*}{$120-220$} & $\mathrm{~N}$ & 50 & 30 & 10 & 2 & - & 1 & - \\
\hline & $X$ & 0.48 & 2.07 & 1.90 & 0.0 & - & 6.0 & - \\
\hline & & $(1.25)$ & $(2.53)$ & $(0.74)$ & $(0.0)$ & - & $(0.0)$ & - \\
\hline
\end{tabular}

Obs: Os valores entre parenteses correspondem ao desvio padrão. 
APENDICE 2. Quadrados médios entre familias, individuos/familia, genes/individuo/familia no modelo hierárquico desbalanceado para cinco alelos do loco Est-1 identificados por eletroforese em uma população natural de Bauhinia forficata. Piracicaba, SP, 1994

F.V.

G.L.

ALELOS

$\begin{array}{lllll}1 & 2 & 3 & 4 & 5\end{array}$

$\begin{array}{lrrrrrrr}\text { Familias } & 12 & 1,7536 & 0,2798 & 0,3070 & 0,5073 & 1,0119 \\ \text { Individuos } & 237 & 0,2023 & 0,0400 & 0,0411 & 0,0759 & 0,1390 \\ \text { Genes } & 250 & 0,2040 & 0,0400 & 0,0520 & 0,0740 & 0,1420\end{array}$


APENDICE 3. Quadrados médios entre famílias, indivíduos/família, genes/individuo/família no modelo hierárquico desbalanceado para três alelos do loco Est-2 identificados por eletroforese em uma população natural de Bauhinia forficata. Piracicaba, SP, 1994

F.V.

G. L.

ALELOS

$1 \quad 3$

$\begin{array}{lrccc}\text { Familias } & 12 & 1,9184 & 0,0294 & 2,0056 \\ \text { Individuos } & 239 & 0,1790 & 0,0186 & 0,1787 \\ \text { Genes } & 252 & 0,2222 & 0,0198 & 0,2103\end{array}$


APENDICE 4. Quadrados médios entre famílias, indivíduos/família, genes/individuo/família no modelo hierárquico desbalanceado para três alelos do loco Est-3 identificados por eletroforese em uma população natural de Bauhinia forficata. Piracicaba, SP, 1994

F.V.

G. L.

ALELOS

$1 \quad 3$

Familias

12

0,8166

0,6357

0,0634

Indivíduos 236

0,2395

0,2430

0,0303

Genes

249

0,2249

0,2189

0,0341 
APENDICE 5. Quadrados médios entre famílias, individuos/família, genes/indivíduo/família no modelo hierárquico desbalanceado para quatro alelos do loco $I d h-1$ identificados por eletroforese em uma população natural de Bauhinia forficata. Piracicaba, SP, 1994

F.V.

G. L.

ALELOS

$\begin{array}{llll}1 & 2 & 3 & 4\end{array}$

$\begin{array}{lccccc}\text { Familias } & 12 & 1,3641 & 0,0438 & 1,1476 & 0,3811 \\ \text { Individuos } & 228 & 0,1524 & 0,0227 & 0,0933 & 0,0648 \\ \text { Genes } & 241 & 0,1660 & 0,0249 & 0,1058 & 0,0685\end{array}$


APENDICE 6. Estimativas das variâncias entre familias $\left(\sigma_{F}^{2}\right)$, entre individuos/familia $\left(: \sigma_{I}^{2}\right)$, entre genes/individuos/familia $\left(\alpha_{a}^{2}\right)$ e da variância total ( $\sigma_{\mathbf{T}}^{2}$ ) para os 15 alelos dos quatro locos isoenzimáticos em uma população natural de Bauhinia forficata. Piracicaba, SP, 1994.

\begin{tabular}{|c|c|c|c|c|c|}
\hline LOCO & ALELO & $\sigma_{F}^{2}$ & $\sigma_{I}^{2}$ & $\sigma_{0}^{2}$ & $\alpha_{T}^{2}$ \\
\hline Est-1 & $\begin{array}{l}1 \\
2 \\
3 \\
4 \\
5 \\
\frac{1}{M}\end{array}$ & $\begin{array}{l}0,0403 \\
0,0062 \\
0,0069 \\
0,0112 \\
0,0227 \\
0,0175\end{array}$ & $\begin{array}{l}-0,0008 \\
2,2.10-6 \\
-0,0054 \\
9,6.10-4 \\
0,0015 \\
-0,0013\end{array}$ & $\begin{array}{l}0,2040 \\
0,0400 \\
0,0520 \\
0,0740 \\
0,1420 \\
0,1024\end{array}$ & $\begin{array}{l}0.2435 \\
0,0463 \\
0,0535 \\
0,0862 \\
0,1632 \\
0,1185\end{array}$ \\
\hline Est-2 & $\begin{array}{l}1 \\
2 \\
3 \\
M\end{array}$ & $\begin{array}{l}0,0449 \\
2,8.10^{-4} \\
0,0473 \\
0,0308\end{array}$ & $\begin{array}{l}-0,0216 \\
-6,1.10^{-4} \\
-0,0158 \\
-0,0127\end{array}$ & $\begin{array}{l}0,2222 \\
0,0198 \\
0,2103 \\
0,1508\end{array}$ & $\begin{array}{l}0,2455 \\
0,0195 \\
0,2418 \\
0,1690\end{array}$ \\
\hline Est-3 & $\begin{array}{l}1 \\
2 \\
3 \\
M\end{array}$ & $\begin{array}{l}0,0151 \\
0,0103 \\
8,6.10^{-4} \\
0,0087\end{array}$ & $\begin{array}{r}0,0073 \\
0,0121 \\
-0,0019 \\
0,0058\end{array}$ & $\begin{array}{l}0,2249 \\
0,2189 \\
0,0341 \\
0,1593\end{array}$ & $\begin{array}{l}0,2473 \\
0,2412 \\
0,0331 \\
0,1738\end{array}$ \\
\hline$I d h-1$ & $\begin{array}{l}1 \\
2 \\
3 \\
4 \\
M\end{array}$ & $\begin{array}{l}0,0327 \\
5,7.10^{-4} \\
0,0284 \\
0,0085 \\
0,0176\end{array}$ & $\begin{array}{l}-0,0068 \\
-0,0011 \\
-0,0063 \\
-0,0018 \\
-0,0040\end{array}$ & $\begin{array}{l}0,1660 \\
0,0249 \\
0,1058 \\
0,0685 \\
0,0913\end{array}$ & $\begin{array}{l}0,1919 \\
0,0244 \\
0,1280 \\
0,0752 \\
0,1048\end{array}$ \\
\hline $\begin{array}{l}\text { MEDIA } \\
\text { MEDIA }\end{array}$ & $\begin{array}{l}\text { GERAL (a ) } \\
\text { GERAL (b ) }\end{array}$ & $\begin{array}{l}0,0187 \\
0,0184\end{array}$ & $\begin{array}{l}-0,0031 \\
-0,0029\end{array}$ & $\begin{array}{l}0,1263 \\
0,1208\end{array}$ & $\begin{array}{l}0,1419 \\
0.1363\end{array}$ \\
\hline
\end{tabular}

(a): Média por loco;

(b): Média por alelo. 